
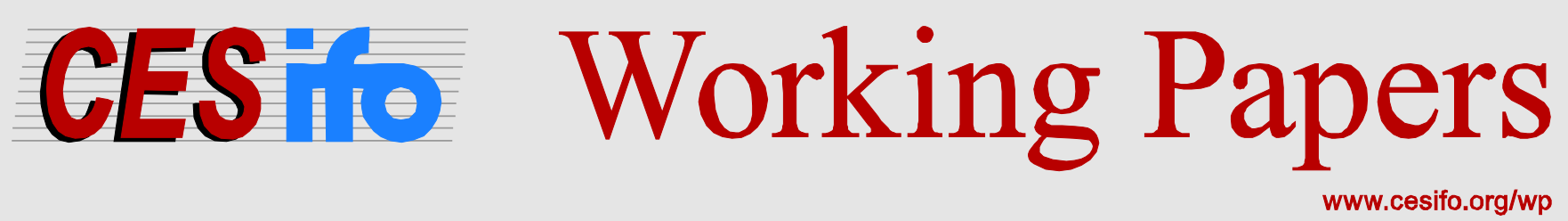

\title{
WTO Membership and the Shift to Consumption Taxes
}

\author{
Thiess Buettner \\ Boryana Madzharova
}

CESIFO WORKING PAPER NO. 6052

CATEgORY 1: PUBlic FinANCE

August 2016

An electronic version of the paper may be downloaded

- from the SSRN website:

- from the RePEc website:

- from the CESifo website:

www.SSRN.com

Www.RePEc.org

www.CESifo-group.org/wp 


\title{
WTO Membership and the Shift to Consumption Taxes
}

\begin{abstract}
Using a panel of 97 mostly developing and transitional countries for the period 1990-2011, this paper explores fiscal implications of membership in the World Trade Organization (WTO). Employing robust difference-in-difference specifications as well as semi-parametric methods, we find that countries joining the WTO experience a decline in revenues from import duties between $0.5 \%$ and $1 \%$ of GDP. Revenue losses from import duties are more than compensated for by an increase in consumption taxes. Although triggered by WTO accession, the shift towards consumption taxes, in particular to VAT, typically takes place before trade liberalization commitments result in declining tariff revenues.
\end{abstract}

JEL-Codes: H200, F130.

Keywords: trade liberalization, tax reform, value added tax, GATT, WTO, anticipation effects, synthetic control group method.

Thiess Buettner

Chair of Economics/Public Finance

University of Erlangen-Nuernberg

Lange Gasse 20

Germany-90403 Nuernberg

thiess.buettner@fau.de
Boryana Madzharova

Chair of Economics/Public Finance

University of Erlangen-Nuernberg

Lange Gasse 20

Germany-90403 Nuernberg

boryana.madzharova@fau.de

July 2016 


\section{Introduction}

Sixty years after it was first introduced in France, the value-added tax (VAT) is currently administered in more than 150 countries and contributes substantially to financing the public sector in many economies (e.g., Tait, 1986; Bird and Gendron, 2007). Academic proposals for optimal tax systems regularly feature VAT as a broad based consumption tax (e.g., IFS and Mirrlees, 2011). Given its success in generating revenue, the VAT is even seen as a "money machine" fostering government expansion (Keen, 2006). While the efficiency properties and the revenue impact of the VAT have been widely acknowledged, the reasons behind its proliferation and the precise timing of its adoption have not been analyzed extensively. In particular, the VAT's role in replacing lost trade taxes as a result of trade liberalization has received limited attention in the economic literature.

By 1990 there was a growing consensus on the importance of combining tariff reform with appropriate fiscal policies to offset revenue losses stemming from tariff reductions (e.g., Mitra, 1992; Linn and Wetzel, 1990). The prevailing concern was that failure to take into account the interdependence of public finances and trade policy could reverse the global trend of declining protectionism, especially in the context of developing economies. ${ }^{1}$ The general recommendation of international institutions such as the International Monetary Fund (IMF) and the World Bank (WB) has been to compensate for the revenue implications of lower tariffs with a concomitant movement towards a broad-based VAT. Besides its revenue potential, VAT's features are in line with the rules of the General Agreement on Tariffs and Trade (GATT) and its successor, the World Trade Organization (WTO). ${ }^{2}$

The theoretical rationale for the substitution of import duties with VAT is presented in Hatzipanayotou et al. (1994) and Keen and Ligthart (2002). The idea is that for a small open economy with a competitive production sector, a reduction in tariffs accompanied by a point-for-point rise in consumption taxes, so that consumer prices remain unchanged, strictly increases welfare and tax revenues. These predictions have been challenged by a stream of theoretical literature, which highlights that the presence of a large informal sector, common in developing countries, could compromise revenue substitution, and, under certain conditions, revenue neutral reforms entail

\footnotetext{
${ }^{1}$ In the mid-1980s, for example, the sustainability of trade reforms in Morocco, Thailand and the Philippines was compromised by unsound fiscal practices, in some cases leading to subsequent tariff increases (Mitra, 1992).

${ }^{2}$ The VAT is consistent with the GATT/WTO rules since it does not discriminate between imports and domestically produced consumption goods. Further, since the credit mechanism compensates for taxes paid on inputs, the tax system does not distort the choice between domestic and foreign inputs (Tait, 1986; Schenk and Oldman, 2007).
} 
welfare losses (Anderson, 1996; Emran and Stiglitz, 2003, 2005).

The concern that compensation of lost import duties through VAT would require higher taxes and consumption prices is not just of theoretical relevance. For successful participation and integration into a free trade regime, it is essential that economies maintain economic and political stability, with revenue stability being an important precondition. This holds in particular for poor and least developed countries currently pursuing trade-liberalization policies in various forms, and especially through accession to the WTO. The empirical assessment of the effectiveness of the trade-cum-tax reform recommendation is therefore an important undertaking.

Despite the importance of the issue, there is scant empirical evidence on countries' actual experience in replacing trade taxes with domestic sources of taxation and with VAT, in particular. In one of the few papers on the subject, Khattry and Rao (2002) test whether total tax revenues are affected by the ratio of international trade taxes to the volume of total trade. This approach has the advantage of using a comprehensive continuous indicator - an implicit tariff or tax rate - that reflects the current state of trade liberalization. ${ }^{3}$ Baunsgaard and Keen (2010) use a similar approach and focus on the relationship between total tax collections and tariff revenues in order to estimate the degree of recovery of lost tariffs. While results differ with respect to the extent to which revenue substitution took place, a common finding of these papers is that low income countries faced difficulties in recouping revenue losses.

As long as tariffs are not completely abolished, changes in revenues from import duties capture not only trade liberalization policies, but also their revenue repercussions, i.e. second-round effects. Since they are likely correlated with overall revenue developments, using tariff revenues as an indicator of liberalization may produce biased estimates of the revenue effects. This point is particularly noteworthy, since the theoretical discussion on the implications of a switch from tariffs to VAT emphasizes the general equilibrium effects of trade liberalization policies. ${ }^{4}$

Another limitation of the existing literature is the implicit assumption that fiscal reforms follow the development of trade tax revenues. The empirical approach taken in the literature typically presumes that tax reforms become effective at about the same time or after revenue losses are realized. Our analysis shows that tax reforms often take place before tariffs are reduced. Far-reaching trade agreements, especially multilateral agreements, often involve intense negotiations. Based on

\footnotetext{
${ }^{3}$ For a summary of the various measures of liberalization used in the literature, see for example Greenway et al. (2002).

${ }^{4}$ To avoid obtaining biased estimates, Baunsgaard and Keen (2010) utilize lagged tariff revenues as instruments.
} 
requests made by other parties, in the course of negotiations, governments obtain an understanding of the scale and scope of the reforms required of them as a prerequisite for membership. Therefore, they might anticipate the revenue losses associated with these reforms and act on their expectations before concessions become binding. Ignoring such ex-ante adjustments could lead to biased estimates of policy effects. ${ }^{5}$ Since low-income countries often tend to raise a significant share of revenues from import duties, trade liberalization might put their public finances at considerable risk. Hence, these countries could be particularly eager to undertake consumption tax reforms in advance of entering a trade agreement. This could explain why the empirical studies have found relatively weak revenue substitution effects for low-income countries.

This paper takes a different approach to assessing the role of consumption taxes as a substitute for import duties. Explicitly distinguishing between trade liberalization policies and their revenue implications, we employ quasi-experimental methods to study revenue losses and revenue substitution as well as the timing of tax reforms vis-a-vis losses from import duties. Rather than employing a tariff-based measure of trade liberalization, we focus on major multilateral trade liberalization events. More specifically, we explore revenue developments in countries that became members of the WTO.

The paper makes three contributions to the literature. First, we show that WTO membership is associated with substantial revenue losses from import duties. Previous studies have indicated that the relationship between GATT/WTO and trade liberalization is weak (e.g., Rose, 2004; 2010). This conforms with evidence that before the Uruguay Round of negotiations initiated in 1986, low income GATT contracting parties undertook only minimal steps towards increasing access to their markets (e.g., Finger et al., 1996). This state of affairs changed considerably during the Uruguay Round: filing of a Schedule of Concessions was made obligatory, and compliance with scheduled obligations could be enforced through the WTO's Dispute Settlement provisions. Our analysis employs a panel of 97, mostly developing and transitional economies, for the period 1990-2011. Using a robust difference-in-difference specification as well as semi-parametric methods, we explore the revenue effects of WTO membership. The results confirm a significant inverse relationship between WTO membership and import duties, supporting the concerns about revenue losses, but also corroborating the efficacy of the late Uruguay GATT and the WTO trade regimes in promoting free trade among new members.

\footnotetext{
${ }^{5}$ See Malani and Reif (2015) for a discussion of biases arising from anticipation effects in the context of tort reform.
} 
The second contribution of the paper is to show that WTO membership is associated with a shift towards consumption taxes. Exploiting the effect of WTO entry on revenues from import duties, we explore whether consumption taxes have been used to compensate for losses in import duties. The empirical results indicate that countries joining the WTO have successfully replaced import duties with consumption taxes and support a significant role of WTO membership as a driver of VAT adoption.

A third contribution is to document differences in the timing between revenue losses from import duties and revenue gains from consumption tax reforms. Cuts in tariffs mostly take place at the time trade liberalization commitments become binding or later, but not earlier. In contrast, changes in consumption taxation exhibit pre-membership effects, as revenues are increased, and VAT is adopted, often years ahead of the losses in import duties. However, we find no effects before the accession negotiations have started. This suggests that the pre-membership effects are not indicative of reverse causation but indicate that consumption tax reforms and VAT adoption are initiated when a country is on the road to WTO membership.

The paper proceeds as follows. The next section provides an overview of the procedures associated with accession to the WTO and its predecessor, the GATT. It also discusses the varying strictness of the agreements and presents descriptive evidence on consumption-tax reforms over the course of accession. Section 3 discusses the methodology of the investigation. The data are described in Section 4. Section 5 reports the empirical results for import duties. Section 6 focuses on consumption tax revenues and VAT. Section 7 concludes.

\section{GATT/WTO Accession and VAT Adoption}

A key element of trade liberalization is the commitment to abstain from policies raising barriers to trade, such as increasing duties on commodities imported from abroad. As this benefits foreign producers, trade liberalization is often part of multilateral agreements that involve similar commitments in foreign markets for domestic producers. In this section we focus on the WTO and its predecessor, the GATT.

The WTO is an intergovernmental organization with currently 162 members accounting for more than $96 \%$ of world trade. It was established in 1994 in Marrakesh after the conclusion of the Uruguay Round of negotiations (1986-1994) and entered into force on January 1st, 1995. It replaced and 
expanded on its predecessor, the GATT. During the Uruguay Round, the GATT evolved into a more intrusive and demanding structure. Originally, GATT only involved negotiations and agreements on trade in goods. The WTO also covers multilateral trade relations in services, intellectual property rights, and international investments through the General Agreement on Trade in Services (GATS) and the Agreement on Trade Related Aspects of Intellectual Property Rights. The extension of the scope of issues regulated by the WTO means that the organization not only commits its members to trade liberalization, but also exercises increasing influence on domestic policy-making (Malhorta, 2003).

As a result of agreements reached in the Uruguay Round, membership in WTO required every participating government to file a Schedule of Concessions and Commitments annexed under GATT 1994 as well as a Schedule of Commitments under GATS. ${ }^{6}$ This was a major change compared with earlier policies: Out of 128 GATT contracting parties, 40 had no Schedule of Concessions in $1986{ }^{7}$ The transition towards a stricter regime was already taking place before the formal establishment of the WTO as evidenced by the fact that 15 out of 17 countries joining GATT between 1990 and 1994 in the dataset used below submitted Schedules.

Since the Schedules were made an integral part of GATT by Article II: 7, concessions recorded in them carry international legal obligations (Bhala, 2008). The implication is that losses in revenue are no longer a remote possibility but a looming prospect. ${ }^{8}$ This does not mean, however, that trade liberalization reforms did not happen in developing countries before. By the time the Uruguay Round was initiated, many of them had already embarked upon autonomous tariff cuts as part of wider economic reforms, for instance, as part of programs with conditionalities by the IMF and the WB. ${ }^{9}$

\footnotetext{
${ }^{6} \mathrm{~A}$ Schedule of Concessions is a document containing an item-by-item list of product categories/services followed by the bound tariffs negotiated on that product/service. The Schedule, therefore, records the maximum rates a member country can possibly apply to a particular product/service. The bound rates generally exceed the actual rates imposed. As new concessions and reductions are negotiated in subsequent trade rounds, members' Schedules are updated accordingly (Bhala, 2008). According to the WTO's Secretariat, "the Schedules bind the actions of member governments with the same force as the Agreement; they represent, in some respects, its 'cash value' "(World Trade Organization, 2009).

${ }^{7}$ The information on pre-Uruguay Schedules of Concessions is sourced from the WTO's website: https://www. wto.org/

${ }^{8}$ Many LDCs acceded to GATT under Article XXVI: 5(c) as former colonies of existing contracting parties. To acquire membership these countries did not have to go through rigorous accession negotiations. In fact, existing GATT parties could not block such accessions and all that was required for the acquisition of membership was the notification of GATT without any promise of reforms (Tang and Wei, 2009).

${ }^{9}$ Unilateral trade-related liberalization measures as well as consumption tax reforms were typical components of IMF/WB conditionalities for the release of funds under the Structural Adjustment Facility (SAF), later replaced by the Poverty Reduction and Growth Facility (PRGF) (Saner and Guilherme, 2007, and Clements et al., 2002).
} 
In addition, relative to pre-1986 GATT, the late Uruguay GATT and the WTO are characterized by a higher level of discipline, stricter rules and enforcement brought about by the Dispute Settlement mechanism. According to Pauwelyn (2005), "unlike GATT Article XXIII, which focused on maintaining a mere balance of concessions, the DSU [Dispute Settlement Understanding - authors' note] for the first time, albeit implicitly, imposes a legally binding obligation to comply with WTO rules and WTO dispute rulings."

Given the transformation of the trade system, accession to the GATT at the end of the Uruguay round and to the WTO is much harder than under the original GATT procedures. ${ }^{10}$ In contrast, WTO accession is more formal and legalistic, requiring members' compliance with a broad spectrum of WTO Agreements as well as detailed obligations pertaining to multiple aspects of trade in order to avoid dispute settlement cases. Since 1995, 35 new members entered the WTO. These accessions usually involved complex negotiations between the applicant government and WTO members and took years as countries needed to revise their domestic laws, regulations and practices in order to accede.

With their flexibility to adjust import duties to current revenue needs curtailed and facing imminent revenue losses, countries joining GATT in the 90s shortly before the WTO's establishment as well as countries entering the WTO directly embarked on reforms of the tax system. While many different options for tax amendments accompanying trade liberalization are possible, reforms involving VAT seem to be an obvious choice, since VAT is a promising substitute for tariffs. The tax base of the VAT has some overlap with import duties because domestic consumption of imported commodities is part of the VAT tax base. Consequently, the IMF and other institutions envisaged reforms that replace import duties by VAT at a rate that leaves consumer prices constant (e.g., IMF, 2005). This might be seen as advantageous as it would mitigate any undesirable distributional effects. However, Emran and Stiglitz (2003) have argued that substitution of tariff revenue by VAT might be difficult in developing countries where often a large part of total production originates in the informal economy. If tariffs are reduced, the substitutability between the informal and the formal sectors may aggravate the decline in revenues from tariffs to such an extent that total revenue decreases with a price-neutral tax reform. More specifically, a fall in tariffs could result in an expansion of the informal sector. Competing imports would decline and, hence, revenue from

\footnotetext{
${ }^{10}$ Jones (2009) describes GATT accession procedures, noting that in the early GATT rounds some countries joined without separate protocols of accession, while others enjoyed considerable flexibility in their negotiations. Jones (2009) argues that varying levels of participation as well as lack of detailed protocols of accession undermined clarity with regard to countries' obligations under the GATT.
} 
tariffs would decline further. A balanced budget reform might, therefore, entail higher tax rates and, consequently, welfare losses (Emran and Stiglitz, 2005). ${ }^{11}$

In practice, close to 60 LDCs and developing economies instituted VAT between 1986 and 1995, many of which are listed in Table A-1 in the Appendix as they are part of our sample discussed below. Figure 1 displays the number of countries introducing VAT over time. ${ }^{12}$ Three distinct time periods can be identified, where the intensity of VAT implementation differs markedly: The early GATT period, the Uruguay Round preceding the WTO, and the WTO period.

During the first period, spanning 1947-1986, lenient entry conditions allowed many countries to join years before they embraced free trade (Hawthorne, 2013). According to Davis and Wilf (2011), frequently foreign policy goals and geopolitical interests outweighted economic considerations, with GATT parties tolerating some degree of free-riding and policies inconsistent with GATT rules.

Until the Uruguay Round, multilateral trade liberalization coupled with tax reform was predominantly restricted to GATT founding members and other developed economies, but barely occurred in lower-income contracting parties. The pioneers of VAT were also the industrialised countries that implemented the tax a few years after entry into effect of the Kennedy/Tokyo Protocols, in line with the staging of tariff reductions.

The Uruguay Round, which marked a move towards stronger trade liberalization, was characterized by a notable wave of VAT adoption. A further wave of VAT adoption is observed during the WTO period. ${ }^{13}$ In spite of some limited transitional periods, the Accession Protocols of many of the new WTO members list the date of membership as an implementation date for the majority of trade commitments. Therefore, while we can view GATT accession dates before the Uruguay Round as a signal for governments' intention to pursue free trade policies in the future, GATT accession after 1990 and direct WTO accessions are more likely to be associated with a swift drop in import

\footnotetext{
${ }^{11}$ As noted by Keen (2008), imperfect revenue substitution of a price-neutral tax reform also hinges on the assumption that the revenue contribution of the informal sector to VAT is zero. Actual VAT systems would involve hidden VAT on informal producers, as VAT on their inputs is not reimbursed.

${ }^{12}$ While for many countries the date of VAT implementation is clear-cut, for others matters are more complicated. Such examples are the cases of Pakistan and Jordan, for instance, that started administering VAT in 1990 and 1994, respectively, but only extended the tax to services and retailers in 1998 (Pakistan) and 2001 (Jordan). In general we consider the date of a fully-fledged VAT to be the relevant point of implementation. Similarly, countries in which VAT excludes services and other activities, like Egypt, are not classified as having VAT but as having a sales tax. Overall, VAT adoption replaced, simplified, and eliminated cascading effects from various forms of sales taxes, manufacturer's/wholesale sales, turnover taxes and other indirect taxes. As of 2011, only fourteen out of the 97 countries considered in this paper do not have a fully-fledged VAT, nine of which are also not WTO members (Table A-1 in Appendix).

${ }^{13}$ For non-GATT countries, accession to the WTO is governed by Article XII of the Marrakesh Agreement establishing the WTO.
} 
Fịure 1: VAT INTRODUCTION (1954-2013)

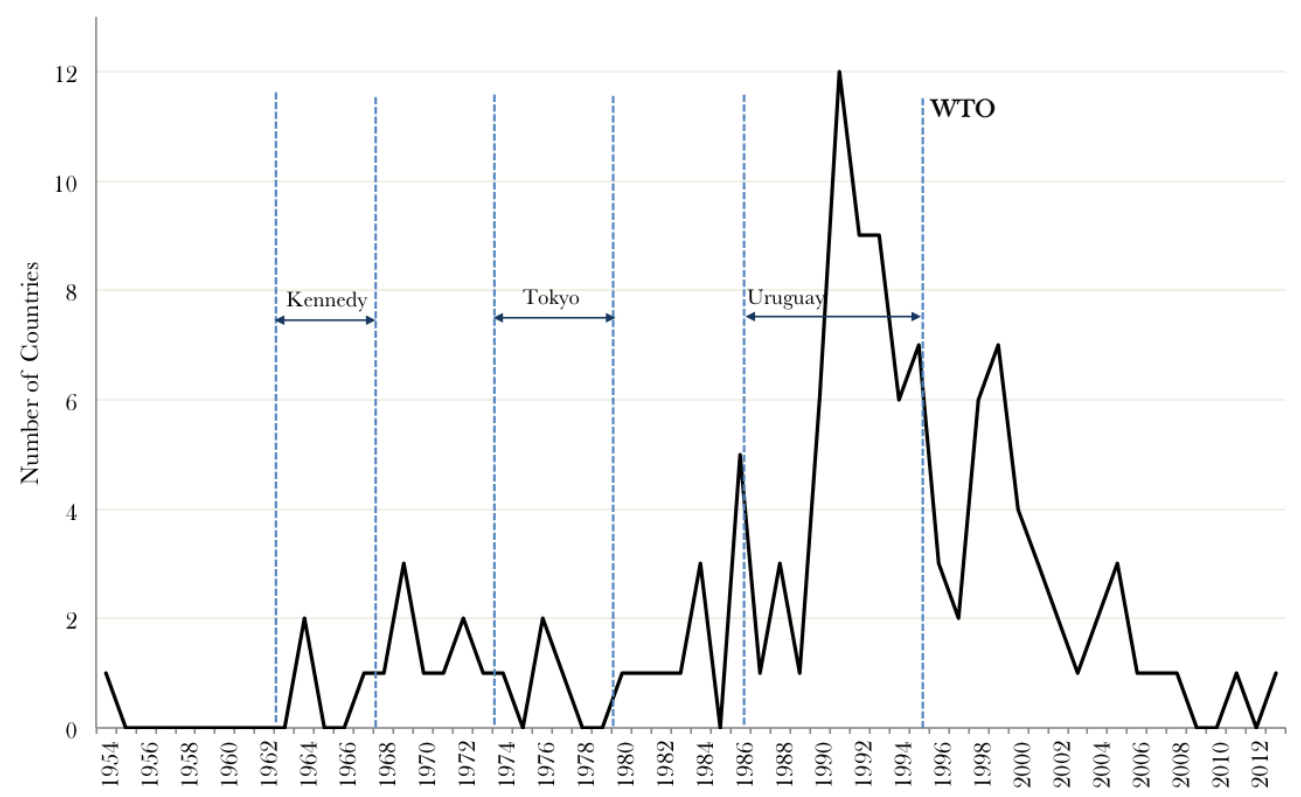

Note: The figure shows VAT introduction years for 121 countries, which include the 97 countries covered in this paper. The duration of the last three GATT rounds of negotiation is also indicated. See Table A-1 in the Appendix for details.

Figure 2: VAT INTRODUCTION VIS-A-VIS WTO MEMBERSHIP

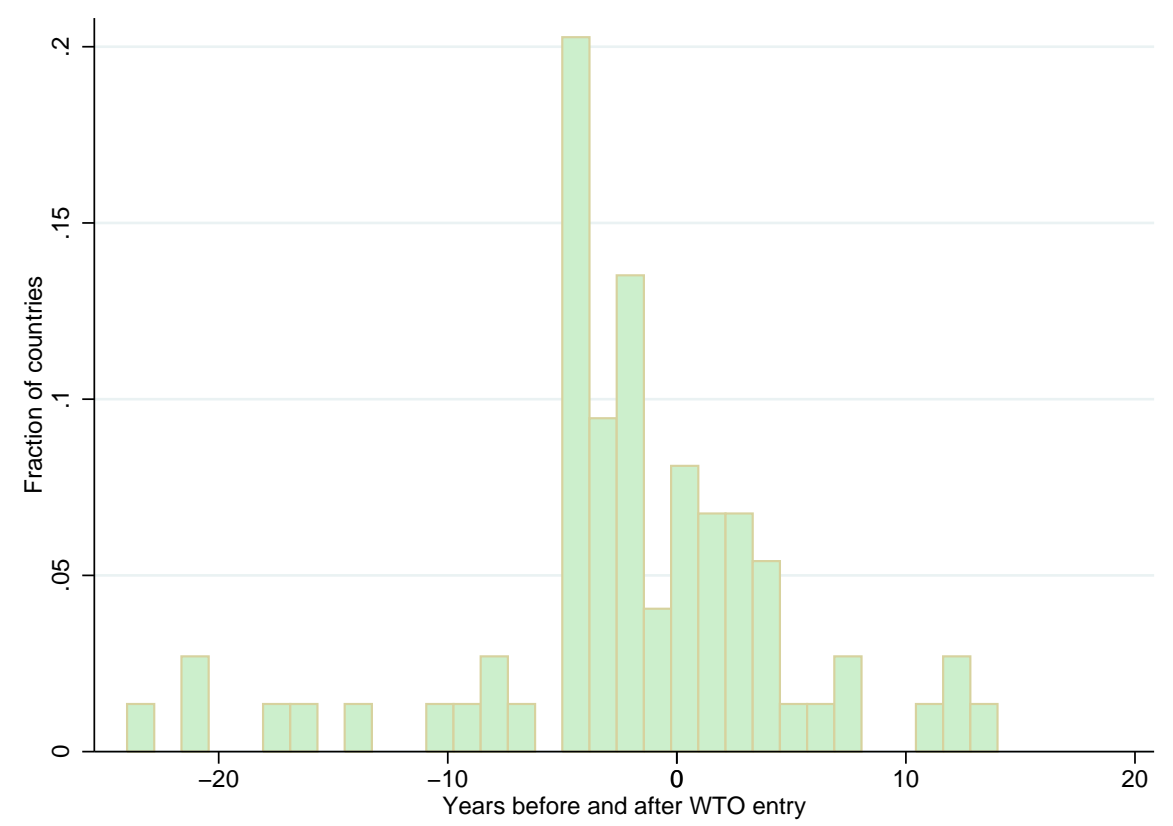

Note: The figure shows how many years before or after WTO entry VAT was introduced in the sample countries. See Table A-1 in the Appendix for details. 
duties.

Figure 2 depicts VAT introduction relative to WTO entry for the countries in our dataset. The figure clearly shows that VAT was mainly instituted in a window of -5 to 5 years around the date of accession. In fact, a large fraction of WTO applicants introduced VAT several years before WTO membership during their entry negotiations. This may reflect anticipatory reforms given expected future declines in revenues from import duties due to the tighter requirements for countries joining GATT/WTO.

\section{Methodology}

The empirical analysis below explores revenue effects of trade liberalization. We identify trade liberalization policies by countries' membership in the WTO and study revenues before and after joining the organization. If current tariffs violate general requirements of this trade agreement, such as the Most-Favored-Nation principle, and if specific concessions are made in order to reach an agreement and to comply with its terms, the corresponding adjustments in tariffs should lead to a decline in tariff revenue.

As noted above, commitments with regard to tariffs also tend to trigger tax reforms, often involving the introduction of VAT or increases in existing VAT rates. Eventually, provided that reforms are successful, gains in VAT will compensate for losses in tariff revenues, making the reform revenueneutral, or yielding a net-revenue increase. Yet, if countries followed the IMF/WB recommendations and implemented price-neutral reforms, given the concerns raised in the literature, we might also find that the net effect is negative, i.e. the sum of collected import duties and consumption taxes decreases.

For a country $i$ joining a trade agreement $(T A)$ in period $t$, a straightforward test of the revenue implications for import duties would explore the difference in revenues before and after $t$. If heterogeneity across countries is captured by fixed effects, and if revenue developments other than those associated with trade liberalization follow common trends, the revenue effects can be analyzed using

$$
T_{i, t}^{I M P}=a_{0, i}+a_{1} I(T A)_{i, t}+x_{i, t}^{\prime} a_{2}+a_{3, t}+\epsilon_{i, t}
$$

where $T_{i, t}^{I M P}$ denotes revenues from import duties in country $i$ in period $t . \quad I(T A)$ is a binary 
indicator reflecting all periods during which the multilateral trade agreement is binding: For all years when the trade policy is subject to the agreement's rules the indicator has value one, $I(T A)_{i, s}=1$ for $s=t, t+1, \ldots$, and zero otherwise. $\epsilon_{i, t}$ is a random disturbance. $a_{0, i}$ is a country-fixed effect; $a_{3, t}$ is a time-fixed effects. $x_{i, t}^{\prime}$ is a vector of control variables capturing other determinants of revenues such as GDP and imports.

Equation (1) is a differences-in-differences (DID) specification, where the coefficient on $I(T A)$ depicts the causal effect of WTO membership on revenues from import duties. More specifically, the coefficient on $I(T A), a_{1}$, reveals by how much revenues from import duties have declined or increased relative to the pre-accession period. Given the weak trade liberalization effects of GATT/WTO found in the previous literature, we might find that the coefficient $a_{1}$ is not statistically different from zero. As noted above, however, major adjustments in enforcement, improved discipline and the specific spell out of commitments through Schedules of Concessions during the Uruguay round as well as the creation of the WTO itself should have strengthened the link between GATT/WTO membership and trade liberalization. Accordingly, we expect to find $a_{1}<0$, indicating revenue losses from import duties.

It is important to note that the empirical effects on import duties are identified from countries that actually joined the WTO. Countries that opted against membership may have reasons to believe that for them the revenue losses are particularly large. As pointed out in the literature studying the effects of international agreements on bilateral trade flows, if countries joining an agreement have "chosen well", unobserved characteristics might give rise to systematic omitted variable bias (Baier and Bergstrand, 2007). Since country-fixed effects are included in the above estimation approach, time-invariant country characteristics that dominate the choice for or against WTO membership are controlled for. Country conditions might have changed nevertheless during the observation period. To some extent this can be controlled for by the explanatory variables $x_{i, t}^{\prime}$. But there might also be developments that are not captured by control variables. Accession countries that take part in certain IMF/WB programs, for instance, are required to pursue trade liberalization policies as part of lending conditionality which might have reduced their cost of WTO accession (see footnote 9). To test whether this affects the empirical results, the analysis also provides estimates excluding countries participating in such programs. We also explore the potentially confounding effect of general economic reforms captured by privatization efforts.

A key assumption of the DID specification is that the dependent variable shows a common trend 
for treated and non-treated observations. ${ }^{14}$ In other words, in the absence of trade liberalization effects, revenue developments in import duties follow common trends among members and nonmembers. An alternative approach that provides valid empirical estimates even if common shocks exert differential effects among subgroups of the population is the synthetic control group method (SCG) pioneered by Abadie and Gardeazabal (2003). The SCG approach has been used in the comparative analysis of policies using aggregate data, where unobservable characteristics exert time-varying effects. Details on the implementation of the SCG methodology for our research question and on the results are provided in the Appendix.

Provided that the data yields a robust WTO membership effect on import duties, in a second step, we explore the implications for consumption tax revenues. Formally,

$$
T_{i, t}^{C O N}=b_{0, i}+b_{1} T_{i, t}^{I M P}+x_{i, t}^{\prime} b_{2}+b_{3, t}+\omega_{i, t}
$$

where $T_{i, t}^{C O N}$ denotes revenues from general consumption taxes in country $i$ in period $t$. If losses in import duties trigger VAT reforms, the sign of $b_{1}$ should be negative, $b_{1}<0$. Critics of the IMF recommendation to substitute import duties with VAT claim that price neutral reforms fail to compensate for lost trade taxes. If governments have nevertheless followed this recommendation, we should observe that $-1<b_{1}<0$. Conversely, provided that lost import duties were being recovered by increased receipts from consumption taxes, $b_{1} \leq-1$.

Note that equations (1) and (2) constitute a structural form of a two-dimensional system. Since revenue shocks for consumption taxes $\omega_{i, t}$ and import duties $\epsilon_{i, t}$ are likely to be correlated, $\mathrm{E}\left[T_{i, t}^{I M P}, \omega_{i, t}\right] \neq$ 0. Estimation of (2), therefore, requires the implementation of a two-stage or instrumental variable approach relying on the variation in $I(T A)$. Based on the assumption that, controlling for $x_{i, t}$, WTO accession affects consumption taxes only indirectly through its effect on import duties, $b_{1}$ is identified.

An alternative specification considers the reduced form representation consisting of equation (1) and an equation for consumption taxes

$$
T_{i, t}^{C O N}=c_{0, i}+c_{1} I(T A)_{i, t}+x_{i, t}^{\prime} c_{2}+c_{3, t}+\eta_{i, t}
$$

where $c_{0, i}$ is a country-fixed effect, $c_{3, t}$ is a time-fixed effect and $\eta_{i, t}$ is a random disturbance.

\footnotetext{
${ }^{14}$ See Lechner (2011) for a discussion of the assumptions underlying difference-in-difference methods.
} 
Provided that membership exerts a downward effect on import duties that prompts tax reforms such as VAT introduction, VAT base broadening, or VAT rate increases, the sign of $c_{1}$ should be positive, $c_{1}>0$. Estimation of the reduced-form equation (2) allows us to see whether the instrumental variable is strong enough to detect the effect of interest (see Angrist and Krueger, 2001). And while estimation of the system (1) and (2) enables us to obtain an estimate of the standard error of the substitution effect, estimation of equations (1) and (3) is sufficient to produce an unbiased point-estimate of the degree of revenue substitution $b_{1}=c_{1} / a_{1} \cdot{ }^{15}$

Rather than relying on changes in tariff revenue as an indicator of trade liberalization policies, specifications (1) and (2) or the reduced form (1) and (3) consider a distinct liberalization episode and explore its revenue consequences for import duties and consumption taxes. More specifically, the analysis considers the response of consumption tax revenues to changes in import duties that are triggered by GATT/WTO entry. The identification of the revenue substitution effect rests basically on two assumptions. The first is that WTO membership has important revenue implications for import duties, an issue that is explored by the analysis of the equation (1). The second assumption is that WTO membership has no direct impact on consumption tax reforms. With regard to the second assumption, it is important to include economic indicators such as GDP and imports as controls also in the equation for consumption tax revenues, as they capture time varying developments that may well change with WTO membership.

A related issue is the timing of WTO accession as the length of negotiation periods might vary and reforms might be accelerated or postponed. Allowing for leading and lagged effects of $I(T A)_{i, t}$, the empirical analysis provides further insights into the timing of the revenue effects and allows us to test for reverse causality. A first question is whether tariff reforms have already been implemented before accession. From the perspective of the negotiation strategy, such pre-accession reforms are problematic as they would undermine the bargaining power of the applicant (e.g., Bond et al., 2003). Pre-membership effects could, however, indicate some reverse causation. Negotiations might speed up for instance, if import duties have already declined, so that expected losses from trade liberalization are reduced. We could also find post-membership effects if the ultimate decision to alter tariffs is postponed, for instance, if agreements include corresponding adjustment periods. ${ }^{16}$

\footnotetext{
${ }^{15}$ Note that the reduced-form equation (3) can also be explored using the SCG approach as outlined in the Appendix.

${ }^{16}$ Developing countries are granted some special provisions under the WTO. The so called General System of Preferences allows developed economies to offer non-reciprocal preferential treatment to exports from their developing trade partners. Further, special exceptions are given from certain obligations due to balance of payments issues and infant industry protection in developing countries.
} 
Consumption tax revenues might also display lagged responses and pre-membership effects. For instance, governments might postpone VAT reform in an attempt to conceal the cost of reaching a trade agreement. For governments following the IMF or WB advice, it is likely that tax reforms are initiated around the time of membership. If substantial revenue losses are anticipated, it might be the case that tax reforms are implemented before membership becomes effective and commitments become binding. While countries joining the WTO do not have full control over the timing of membership, one could argue that in the presence of concerns about revenue substitution, candidates may delay negotiations until the success of a consumption tax reform can be evaluated. In this case, pre-membership effects would be indicative of reverse causation.

To test for lagged responses and pre-membership effects, we extend the reduced-form specification (1) and (3) to include leads and lags of $I(T A)$ following Autor (2003) and Malani and Reif (2015). Formally, with $q, p \geq 1$

$$
\begin{aligned}
T_{i, t}^{I M P} & =a_{0, i}+\sum_{s=1-q}^{p} \alpha_{y+s} \overline{I(T A)}_{i, t}^{y+s}+a_{1} I(T A)_{i, t-q}+x_{i, t}^{\prime} a_{2}+a_{3, t}+\epsilon_{i, t}, \\
T_{i, t}^{C O N} & =c_{0, i}+\sum_{s=1-q}^{p} \gamma_{y+s}{\overline{I(T A)_{i, t}}}_{i+s}+c_{1} I(T A)_{i, t-q}+x_{i, t}^{\prime} c_{2}+c_{3, t}+\eta_{i, t} .
\end{aligned}
$$

Upper-bar variables refer to years before or after WTO entry. ${\overline{I(T A)_{i, t}}}^{y+1}$, for instance, has a value of one in the year before entry, ${\overline{I(T A)_{i, t}}}^{y}$ in the year of entry, and ${\overline{I(T A)_{i, t}}}^{y-1}$ in the first year after entry. The specifications also employ a dummy variable capturing the remaining time period under membership, $I(T A)_{i, t-q}$. For $q, p=1$, the year before WTO membership shows a significant effect if $\alpha_{y+1} \neq 0$ or $\gamma_{y+1} \neq 0$. The year of membership is allowed to exert a different effect than the long-run effect, as $\alpha_{y}$ may differ from $a_{1}$ and $\gamma_{y}$ may differ from $c_{1}$. If $\alpha_{y}=a_{1}, \gamma_{y}=c_{1}$, and $\alpha_{y+1}=0, \gamma_{y+1}=0$, we obtain the basic reduced-form specification (1) and (3). A negative $\alpha_{y+1}$ would be evidence of pre-membership effects, suggesting that import duties start declining before WTO accession. A positive $\gamma_{y+1}$ would indicate that consumption taxes are rising before entry. By setting larger values for $q, p$, further periods before and after accession can be included in the test. To identify the period when revenue losses from import duties may be expected although not yet realized, we provide results from an alternative specification for consumption taxes which sets $I(T A)=1$ at the start of negotiations about WTO accession. More precisely, we refer to the date of submission of a Memorandum. It is only after a country submits this detailed summary of its foreign trade regime that negotiations with existing WTO members can begin in earnest. The 
Memorandum includes a description of laws, legal acts, import licensing procedures, customs valuation, list of foreign trade agreements and other supporting information. Without this collection of information on the table, which represents a considerable investment of resources by the candidate, the Working Party, established whenever there is a new request for accession, cannot prepare its Report and negotiations cannot move forward. ${ }^{17,18}$ If we find significant effects for consumption taxes in the periods before a Memorandum submission, however, the pre-membership effects are perhaps not driven by anticipation but are rather indicative of reverse causation: countries would first introduce VAT and then start to negotiate about WTO accession conditional on the revenue performance.

\section{Data}

The data used to analyze the revenue implications of WTO entry covers 97 countries over the period 1990-2011. As of 2011 this includes 72 WTO members and 25 non-members. The data captures existing contracting parties of GATT in 1990. It also contains countries joining GATT during the last stages of the Uruguay Round, and countries that acceded to the WTO directly. Several current WTO members and a handful of non-members are left out mainly because in the data sources it proved impossible to obtain separate figures for general consumption tax revenue and/or revenues from import duties for these countries. For others the figures are unreliable, or missing. The problem is also described in Baunsgaard and Keen (2010) specifically concerning the IMF's Government Finance Statistics database. High-income industrialized countries that implemented trade liberalization and general consumption taxes early on as well as oil-rich Middle Eastern countries that have a rather specific revenue structure are not included in our analysis.

The data consists of information on general consumption taxes, collected domestically and at the border, import duties, total tax revenue, imports, the share of agriculture in GDP, as well as GDP and GDP per capita. We performed standard tests for outliers and removed several years surrounding the transitions of the centrally planned European economies towards free markets (Albania, Bulgaria, the Czech Republic, Croatia, Lithuania, Poland, and Romania) as well as few data points for Malta and Tanzania in the early $90 \mathrm{~s} .{ }^{19}$ The definitions of all variables and their

\footnotetext{
${ }^{17}$ More information on the accession process can be found here: https://www.wto.org/english/thewto_e/acc_ e/cbt_course_e/c4s1p1_e.htm

${ }^{18}$ Jones (2009) also points out that many candidate countries are not aware of the nature of the scope of the required reforms until the negotiations begin.

${ }^{19}$ Import duties do not include other duties or charges discriminating against imports such as stamp duties, de-
} 
Table 1: DESCRIPTIVE STATISTICS

\begin{tabular}{lccccc}
\hline \hline & Mean & SE & Min & Max & N \\
\cline { 2 - 5 } Import duties per GDP & 2.50 & 3.13 & 0 & 35.05 & 1842 \\
Consumption taxes per GDP & 5.06 & 2.72 & .103 & 16.13 & 1808 \\
Agric. prod. per GDP & 17.29 & 13.82 & .037 & 65.97 & 2107 \\
Imports per GDP & 48.15 & 24.99 & 6.47 & 211.92 & 2130 \\
GDP per capita & 5926 & 9672 & 113 & 61662 & 2117 \\
$I(T A)$ & .632 & .480 & 0 & 1 & 2134 \\
$I(V A T)$ & .587 & .487 & 0 & 1 & 2134 \\
\hline
\end{tabular}

Note: The table depicts summary statistics: mean, standard error, minimum and maximum value, as well as number of observations. GDP per capita in constant 2005 USD. $I(T A)$ is a dummy variable reflecting the time of membership in GATT/WTO. I $V A T)$ is a dummy variable, which equals one when a country implements full-fledged VAT. See Table A-2 for further details on the sources and definitions of variables.

sources are listed in Table A-2 in the Appendix. ${ }^{20}$ See Table A-3 for basic descriptive statistics.

The general development of revenues from import duties and consumption taxes from 1990 to 2011 for the new WTO members, the 1990-1994 GATT signatories, the pre-1990 GATT contracting parties and the non-members is broadly consistent with expectations. At the end of the period of observation GATT signatories report the lowest revenues from import duties among all countries. Non-members collect the highest amount of import duties in percent of GDP in 2011. At the end of the observation period, also consumption tax revenues are highest among the new WTO members and the 1990-1994 GATT signatories (see Table A-3 and Figures A-1 and A-2 in the Appendix). A dummy variable is used to reflect the timing of GATT and WTO membership: $I(T A)$, where $T A$ stands for trade agreement. It equals 1 for the years, in which a country is a GATT or WTO member, and is zero otherwise. For the year of membership itself, $I(T A)$ equals the number of days after the entry date divided by the total number of days in that year, thus capturing within-year variation. 41 countries in the data became GATT contracting parties before 1990, when the panel begins. For them, therefore, $I(T A)$ equals 1 for the whole duration of the panel. 17 countries entered GATT in the period 1990-1994. These were Uruguay Round participants, who submitted and gained approval for their GATT and GATS schedules before 1 January 1995. 14 countries were not GATT contracting parties before 1995. They acceded directly into the WTO. For these

velopment tax, etc. Consumption taxes exclude excises and other indirect taxes whenever possible, with very few exceptions when these could not be separated.

${ }^{20}$ Basically, the variables were collected from IMF individual country Reports, predominately from the statistical appendices that sometimes accompany these publications and from Recent Developments reports generally covering the early 90s. Article IV consultations were also used as a source of information. Eurostat data and OECD Tax Revenue Statistics were used for the European and Latin American countries in the data. Whenever possible, the data has been crossed-checked with statistics from the national statistical offices, ministries of finance, central banks as well as from numerous country-specific publications. 
countries, $I(T A)$ coincides with the date of WTO entry. It is these $31(=17+14)$ countries in the data that provide the identifying variation in the treatment variable $I(T A)$. The remaining 25 countries are non-members, current WTO observers, or former observers who joined the WTO after 2011, which is the last year in the panel. ${ }^{21}$ See Table A-1 in the Appendix for details on years of VAT adoption and GATT/WTO entry.

\section{$5 \quad$ WTO Accession and Revenues from Import Duties}

Table 2 reports the effect of WTO membership on import duties following equation (1). Column (1) starts out with a basic differences-in-differences estimation that includes only country- and year-fixed effects. To avoid possible random-group effects, inference is based on standard errors clustered at the level of countries as suggested by Bertrand et al. (2004). The negative coefficient of $I(T A)$ indicates a considerable reduction in tariff revenue due to entry into GATT/WTO. In column (2) the coefficient becomes slightly larger when the regression incorporates GDP per capita, agriculture and imports in percent of GDP, all of which prove insignificant. The point estimate of the mean effect of $I(T A)$ translates into considerable revenue losses amounting to about $0.73 \%$ of GDP. To capture possible changes in the size of the public sector, the specification in column (3) presents results with total revenue as a share of GDP. Including this control does not yield a much different estimate indicating that the revenue shortfall associated with GATT/WTO accession is not driven by changes in the size of the government.

While the magnitude of the treatment effect enables us to see how large the revenue losses have been, its statistical significance is of interest in itself. The time span of the data, 1990-2011, covers a period when the GATT evolved from a system with weak rules and lack of effective enforcement to high legalization and discipline, strict enforcement and high demand for participation and political input (Pauwelyn, 2005). These developments should have been conducive to improving accession countries' compliance with multilateral trade rules, with corresponding downward adjustments in trade taxes. The significantly negative estimated effect of late-Uruguay GATT/WTO membership on import duties indeed confirms this hypothesis.

To uncover if the strictness of the trade regime varies between 1990-1994 and the WTO period, column (4) includes an interaction term for the 14 countries in our sample that joined the WTO directly. This term has no significant effect indicating that the magnitude of the treatment does

\footnotetext{
${ }^{21}$ WTO observers must initiate accession negotiations within five years of obtaining an observer status.
} 
Table 2: REVENUES FROM IMPORT DUTIES \& GATT/WTO ENTRY

\begin{tabular}{|c|c|c|c|c|c|c|}
\hline & (1) & $(2)$ & $(3)$ & (4) & $(5)$ & (6) \\
\hline$I(T A)$ & $\begin{array}{c}-.620^{* *} \\
(.294)\end{array}$ & $\begin{array}{c}-.731^{* *} \\
(.300)\end{array}$ & $\begin{array}{c}-.685^{* *} \\
(.304)\end{array}$ & $\begin{array}{c}-.749^{*} \\
(.429)\end{array}$ & $\begin{array}{c}-.810^{* * *} \\
(.303)\end{array}$ & $\begin{array}{c}-.905^{* *} \\
(.401)\end{array}$ \\
\hline$I(T A) \times I($ new $)$ & & & & $\begin{array}{c}.030 \\
(.585)\end{array}$ & & \\
\hline $\log G D P$ & & $\begin{array}{c}.636 \\
(.509)\end{array}$ & $\begin{array}{c}.689 \\
(.486)\end{array}$ & $\begin{array}{c}.630 \\
(.496)\end{array}$ & $\begin{array}{c}.553 \\
(.523)\end{array}$ & $\begin{array}{l}-.135 \\
(.505)\end{array}$ \\
\hline Agric. & & $\begin{array}{l}-.015 \\
(.018)\end{array}$ & $\begin{array}{l}-.001 \\
(.018)\end{array}$ & $\begin{array}{l}-.012 \\
(.018)\end{array}$ & $\begin{array}{l}-.015 \\
(.017)\end{array}$ & $\begin{array}{c}-.051^{*} \\
(.027)\end{array}$ \\
\hline Imp. & & $\begin{array}{c}.002 \\
(.008)\end{array}$ & $\begin{array}{l}-.000 \\
(.007)\end{array}$ & $\begin{array}{c}.003 \\
(.009)\end{array}$ & $\begin{array}{c}.004 \\
(.007)\end{array}$ & $\begin{array}{l}-.002 \\
(.010)\end{array}$ \\
\hline TotalRev. & & & $\begin{array}{l}.094^{* *} \\
(.044)\end{array}$ & & & \\
\hline Constant & $\begin{array}{c}3.60^{* * *} \\
(.226) \\
\end{array}$ & $\begin{array}{l}-1.02 \\
(4.03) \\
\end{array}$ & $\begin{array}{l}-3.12 \\
(3.79) \\
\end{array}$ & $\begin{array}{l}-.968 \\
(3.93) \\
\end{array}$ & $\begin{array}{l}-.748 \\
(4.17) \\
\end{array}$ & $\begin{array}{c}5.32 \\
(4.23) \\
\end{array}$ \\
\hline Observ. & 1,842 & 1,842 & 1,836 & 1,842 & 1,713 & 1,274 \\
\hline Countries & 97 & 97 & 97 & 97 & 88 & 68 \\
\hline
\end{tabular}

Notes: The sample refers to 1990-2011. Dependent variable is revenue from import duties in percent of GDP. $I(T A)=1$ if a country is member of GATT/WTO, and 0 otherwise. $I(n e w)=1$ if a country has joined WTO after 1995. Agric., Imp., TotalRev. are the values of agriculture, imports, and tax revenue in percent of GDP. $\log G D P$ is the logarithm of per capita GDP. Column (5) excludes the 9 countries that joined WTO after 2011. Column (6) excludes 29 countries that received loans from the IMF's PRGF program. Country- and year-fixed effects included. Standard errors are clustered by country in all specifications. Asterisks denote significance at the $1 \%\left({ }^{* * *}\right), 5 \%\left({ }^{* *}\right)$, and $10 \%\left({ }^{*}\right)$ levels.

not vary between these two subgroups. We interpret this as evidence of the stricter trade regime prevailing already at the end of the Uruguay Round before the transition from the GATT to the WTO.

A potential problem may arise with regard to non-members of GATT/WTO that serve as a control group in the regressions. Given that some of them started accession negotiations during the observation period, it is possible that adjustments are already under way, which would introduce a downward bias in our setting. Nine of these countries (the Russian Federation, Montenegro, Samoa, Vanuatu, Laos, Tajikistan, Yemen, the Seychelles and Kazakhstan) in fact joined the WTO after 2011, which is the last year in our dataset. If import duties in these countries declined in the later years of their entry negotiations, the estimate of $I(T A)$ would underestimate the effect of membership. To check this, we remove these countries and report results in column (5). The results are similar to the baseline estimate (2).

As mentioned above, our focus on multilateral agreements leaves out the effects of other trade 
Table 3: IMPORT DUTIES: EFFECTS PRE- \& POST ENTRY

\begin{tabular}{|c|c|c|c|}
\hline & (1) & $(2)$ & (3) \\
\hline${\overline{I(T A)_{t}}}_{t}^{y+2}$ & & $\begin{array}{l}.128 \\
(.339)\end{array}$ & $\begin{array}{c}.163 \\
(.410)\end{array}$ \\
\hline$\overline{I(T A)}_{t}^{y+1}$ & $\begin{array}{l}-.201 \\
(.248)\end{array}$ & $\begin{array}{l}-.161 \\
(.336)\end{array}$ & $\begin{array}{l}-.143 \\
(.361)\end{array}$ \\
\hline${\overline{I(T A)_{t}}}_{t}^{y}$ & $\begin{array}{l}-.399 \\
(.253)\end{array}$ & $\begin{array}{l}-.359 \\
(.325)\end{array}$ & $\begin{array}{l}-.293 \\
(.431)\end{array}$ \\
\hline${\overline{I(T A)_{t}}}_{t}^{y-1}$ & & & $\begin{array}{l}-.321 \\
(.383)\end{array}$ \\
\hline$I(T A)_{t-1}$ & $\begin{array}{c}-.812^{* *} \\
(.363)\end{array}$ & $\begin{array}{l}-765^{*} \\
(.422)\end{array}$ & \\
\hline$I(T A)_{t-2}$ & & & $\begin{array}{c}-.812^{*} \\
(.456)\end{array}$ \\
\hline $\log G D P$ & $\begin{array}{c}.617 \\
(.570)\end{array}$ & $\begin{array}{c}.593 \\
(.607)\end{array}$ & $\begin{array}{c}.516 \\
(.564)\end{array}$ \\
\hline Agric. & $\begin{array}{l}-.013 \\
(.018)\end{array}$ & $\begin{array}{l}-.012 \\
(.018)\end{array}$ & $\begin{array}{l}-.011 \\
(.017)\end{array}$ \\
\hline Imp. & $\begin{array}{l}-.003 \\
(.009)\end{array}$ & $\begin{array}{l}-.002 \\
(.008)\end{array}$ & $\begin{array}{l}-.006 \\
(.009)\end{array}$ \\
\hline Constant & $\begin{array}{l}-.644 \\
(4.47) \\
\end{array}$ & $\begin{array}{l}-.535 \\
(4.73)\end{array}$ & $\begin{array}{c}.164 \\
(4.37) \\
\end{array}$ \\
\hline Observ. & 1,709 & 1,627 & 1,563 \\
\hline Countries & 97 & 97 & 97 \\
\hline
\end{tabular}

Notes: The sample refers to 1990-2011. The dependent variable is revenue from import duties in percent of GDP. Agric. and Imp. are the values of agriculture and imports in percent of GDP. $\log G D P$ is the logarithm of per capita GDP. All columns include country- and year-fixed effects. ${\overline{I(T A)_{t}}}_{t}^{y+s}$ equals one $s$ years prior to GATT/WTO membership, and $\overline{I(T A)}_{t}^{y-s}$ equals one $s$ years after entry. $I(T A)_{t-j}$ equals one for all years starting after the j-th year of membership. Standard errors are clustered by country in all specifications. Asterisks denote significance at the $1 \%\left({ }^{* * *}\right), 5 \%\left({ }^{* *}\right)$, and $10 \%(*)$ levels.

liberalization reforms. This might introduce a downward bias to the estimated coefficients in equation (1) as countries joining the WTO may already exhibit lower revenues from import duties. One way to check for downward bias stemming from unilateral policies is to exclude the 29 countries in our sample that have received funds from the IMF under the Poverty Reduction and Growth Facility as they have likely been subject to trade related conditionalities. ${ }^{22}$ They are listed in bold in Table A-1 (see Appendix) and comprise of both accession and non-accession countries. Column

\footnotetext{
${ }^{22}$ Saner and Guilherme (2007) point out that $80 \%$ of countries participating in 56 programmes under SAF/PRGF have been imposed a trade reform measure with a binding mode of conditionality concerning the disbursement arrangements of the IMF. In the early 1990s, trade policy reform accounted for 30\% of the conditions in the World Bank adjustment lending. Sub-Saharan Africa, in particular, is subjected to extensive and comprehensive trade liberalization reforms concerning tariffs, non-tariff barriers and customs administration.
} 
(6) of Table 2 presents the outcome of this exercise. The slope coefficient turns out to be slightly larger than the baseline estimate from column (2). This lends credence to the view that among countries bound by IMF conditionality some trade liberalization measures may have already been implemented, mitigating the revenue loss from WTO accession. ${ }^{23}$

Using the extended specification in equation (4), Table 3 sheds light on whether import duties start diminishing before the respective WTO membership dates. In column (1) we check for premembership effects 1 year before treatment and allow for lagged response by including separate indicators for the first and all other years of membership. ${ }^{24}$ In column (2) we add an indicator for the period 2 years before treatment. None of the leads are statistically significant demonstrating that import duties do not decrease before membership. One explanation could be that countries are unwilling to implement concessions during the trade negotiations, as this would undermine their bargaining position. In fact, the significant effect of the lagged accession dummy in columns (1) and (2) suggests that import duties decline after membership, which is in line with implementation delays or pre-agreed implementation periods. This view is confirmed in column (3) where we add a further post-treatment indicator for the second year after the date of entry: Membership takes two years to show a significant effect.

To assess the effects of WTO entry under the more general assumption that unobserved country characteristics give rise to differential trends, we employ the SCG method mentioned above. The methodology and the results based on the SCG approach are described in detail in the Appendix. In many cases the fit between the actual revenue development before WTO accession and the synthetic control group is modest. Nevertheless, without exception, in the periods after accession import duties are found to be smaller in member countries compared to the synthetic control group. As shown in the Appendix, these treatment effects are found to differ from random responses. The Appendix also provides means of covariates and outcomes for the respective country and its synthetic control group. The average difference between import duties of treated countries and their synthetic control groups amounts to -0.27 . While this points to a smaller decline compared with the results in Table 2, it should be noted that the 9 countries included in the SCG analysis

\footnotetext{
${ }^{23}$ It is also possible that WTO membership not only triggers trade reform but also other economic reforms that have revenue implications for consumption taxes. Using the World Bank's Private Participation in Infrastructure Database as well as the Privatization Barometer Database, we constructed an index of annual privatization efforts for our sample of countries. The results show that accounting for privatization does not alter the effect of WTO membership on consumption taxes (results available upon request).

${ }^{24}$ Note that the within year variation is suppressed in the construction of membership indicators when testing for anticipation and lagged response.
} 
also report lower import duties before the treatment.

\section{Revenue Substitution by Consumption Taxes}

Table 4 displays basic results for the effect of WTO membership on consumption tax revenues using the reduced form specification of equation (3). The fixed effects regression in Column (1) shows that the period following WTO entry is characterized by a significant increase in consumption tax receipts. With controls for GDP per capita and the shares of agriculture and imports, the results indicate a revenue gain amounting to about $1 \%$ of GDP. Column (2) controls for total revenues to test whether the revenue increase reflects a change in the revenue structure or is associated with an expansion of the public sector. The latter might result from the higher efficiency of a tax system that relies more heavily on VAT (Keen and Lockwood, 2010). The point estimate for the treatment effect, however, is not affected when total revenues enter the regression.

Table 4: CONSUMPTION TAXES AND GATT/WTO MEMBERSHIP

\begin{tabular}{lcccc}
\hline \hline & $(1)$ & $(2)$ & $(3)$ & $(4)$ \\
\cline { 2 - 5 } I T $A)$ & $1.24^{* *}$ & $1.38^{* *}$ & $1.24^{* *}$ & $1.56^{* *}$ \\
logGDP & $(.497)$ & $(.483)$ & $(.496)$ & $(.747)$ \\
& -1.21 & -1.10 & $-1.31^{*}$ & -1.93 \\
Agric. & $(.740)$ & $(.673)$ & $(.760)$ & $(1.01)$ \\
& $-.041^{* *}$ & -.019 & $-.050^{* *}$ & -.032 \\
Imp. & $(.019)$ & $(.018)$ & $(.018)$ & $.039)$ \\
& $.013^{*}$ & .007 & .011 & $(.008)$ \\
TotalRev. & $(.007)$ & $(.006)$ & $(.008)$ & \\
Constant & & $.148^{* * *}$ & & $19.4^{* *}$ \\
& $12.5^{* *}$ & $(.029)$ & $13.4^{*}$ & $(8.44)$ \\
\hline Observ. & $(5.75)$ & $9.00^{*}$ & $(5.90)$ & 1,209 \\
Countries & 1,760 & $(5.15)$ & 1,639 & 67 \\
\hline
\end{tabular}

The sample refers to 1990-2011. The dependent variable is revenue from consumption taxes in percent of GDP. $I(T A)$ equals 1 if a country is GATT/WTO member, and 0 otherwise. Agric., Imp., TotalRev. are the values of agriculture, imports, and tax revenue in percent of GDP. $\log G D P$ is the logarithm of per capita GDP. Column (3) excludes 9 WTO members that joined after 2011. Column (4) excludes 29 countries that received loans from the IMF's PRGF Program. All columns include country- and year-fixed effects. Standard errors are clustered by country in all specifications. Asterisks denote significance at the $1 \%\left(^{* * *}\right), 5 \%\left(^{* *}\right)$, and $10 \%\left({ }^{*}\right)$ levels.

Columns (3) and (4) present some robustness checks. Column (3) excludes the 9 countries joining the WTO after 2011 from the set of non-treated observations, as possible adjustments may already 
have occurred during the observation period. Results are unchanged indicating that this concern is not supported. Column (4) drops the 29 countries that took or take part in the IMF's PRGF program, since these countries may have undertaken policies of trade liberalization as well as tax reforms as part of IMF conditionality. As a result, the effect on consumption tax revenues increases to a point estimate of $1.56 \%$ of GDP. This suggests that IMF conditionality may confound the treatment effect in the basic specification.

To test systematically for timing effects, we report results from a specification following equation (5) which includes leads and lags of the treatment dummy. The results are depicted in Table 5. Columns (1), (2) and (3) add one lead at a time. The results show that leads two years before treatment are statistically significant.

The pre-membership effects could possibly reflect a forward looking tax policy that institutes reforms before the revenue consequences of WTO membership affect the budget. An alternative explanation is one of reverse causation, where countries pursue WTO accession only after a successful consumption tax reform. To distinguish anticipation from reverse causation, we consider consumption tax developments before and after the start of WTO negotiations. More specifically, in order to identify the period, when revenue losses from import duties are expected but not yet realized, we use the date of Memorandum submission. 14 countries in our sample acceded to the WTO under Article XII of the Marrakesh Agreement with its more complicated entry procedures, and submitted a Memorandum. For these countries we change the treatment variable $I(T A)$ by replacing the date of WTO entry with the date of Memorandum submission. Results are presented in columns (4) to (7) of Table 5. Column (4) includes a lead and a lag of the year of the Memorandum submission (membership year for the GATT parties). Columns (5) and (6) add further leads. In all three specifications the lead terms are not statistically different from zero, indicating that consumption taxes do not respond before the date of Memorandum submission (GATT membership). Therefore, pre-membership effects are not driven by reverse causation, but rather show that consumption tax reforms are initiated when a country is firmly on the road to WTO membership. Note that the estimation yields stronger long-run responses of consumption taxes when differences in timing are taken into account. Compared to an increase of revenues by $1.24 \%$ of GDP in column (2) of Table 4, column (1) of Table 5 reports a point estimate of $1.42 \%$ of GDP and column (4) reports an estimate of $1.39 \%$. Unlike the WTO accession protocols, the entry procedure for the 17 countries joining GATT between 1990 and 1994 was not standardized. For them, the 
Table 5: CONSUMPTION TAXES: EFFECTS PRE- \& POST ENTRY

\begin{tabular}{|c|c|c|c|c|c|c|c|c|}
\hline & (1) & $(2)$ & (3) & 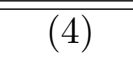 & (5) & (6) & (7) & $\overline{(\overline{(8)})}$ \\
\hline${\overline{I(T A)_{t+3}}}_{t}$ & & & $\begin{array}{c}.604 \\
(.574)\end{array}$ & & & $\begin{array}{l}-.097 \\
(.555)\end{array}$ & $\begin{array}{l}-.056 \\
(.407)\end{array}$ & $\begin{array}{c}.100 \\
(.112)\end{array}$ \\
\hline${\overline{I(T A)}}_{t+2}$ & & $\begin{array}{l}.999^{*} \\
(.508)\end{array}$ & $\begin{array}{l}1.09^{*} \\
(.591)\end{array}$ & & $\begin{array}{c}-.045 \\
(.506)\end{array}$ & $\begin{array}{l}-.141 \\
(.609)\end{array}$ & $\begin{array}{l}-.135 \\
(.342)\end{array}$ & $\begin{array}{c}.112 \\
(.096)\end{array}$ \\
\hline${\overline{I(T A)}}_{t+1}$ & $\begin{array}{l}1.11^{* *} \\
(.511)\end{array}$ & $\begin{array}{l}1.31^{* *} \\
(.588)\end{array}$ & $\begin{array}{l}1.40^{* *} \\
(.652)\end{array}$ & $\begin{array}{c}.672 \\
(.443)\end{array}$ & $\begin{array}{l}.608 \\
(.520)\end{array}$ & $\begin{array}{c}.496 \\
(.587)\end{array}$ & $\begin{array}{c}.963 \\
(.795)\end{array}$ & $\begin{array}{c}.073 \\
(.092)\end{array}$ \\
\hline${\overline{I(T A)_{t}}}_{t}$ & $\begin{array}{l}1.51^{* *} \\
(.646)\end{array}$ & $\begin{array}{l}1.71^{* *} \\
(.705)\end{array}$ & $\begin{array}{l}1.80^{* *} \\
(.763)\end{array}$ & $\begin{array}{l}.833^{* *} \\
(.360)\end{array}$ & $\begin{array}{l}.754^{*} \\
(.424)\end{array}$ & $\begin{array}{c}.627 \\
(.494)\end{array}$ & $\begin{array}{c}.828 \\
(.667)\end{array}$ & $\begin{array}{l}.136 \\
(.093)\end{array}$ \\
\hline$I(T A)_{t-1}$ & $\begin{array}{l}1.42^{* *} \\
(.606)\end{array}$ & $\begin{array}{l}1.60^{* *} \\
(.650)\end{array}$ & $\begin{array}{l}1.67^{* *} \\
(.702)\end{array}$ & $\begin{array}{c}1.39^{* * *} \\
(.514)\end{array}$ & $\begin{array}{l}1.27^{* *} \\
(.543)\end{array}$ & $\begin{array}{l}1.10^{*} \\
(.588)\end{array}$ & $\begin{array}{l}1.75^{* *} \\
(.693)\end{array}$ & $\begin{array}{l}.251^{* *} \\
(.097)\end{array}$ \\
\hline $\log G D P$ & $\begin{array}{l}-1.34^{*} \\
(.715)\end{array}$ & $\begin{array}{r}-1.38^{* *} \\
(.694)\end{array}$ & $\begin{array}{r}-1.35^{* *} \\
(.665)\end{array}$ & $\begin{array}{l}-1.00 \\
(.617)\end{array}$ & $\begin{array}{l}-.971 \\
(.609)\end{array}$ & $\begin{array}{l}-.898 \\
(.595)\end{array}$ & $\begin{array}{l}-.657 \\
(695)\end{array}$ & $\begin{array}{c}.019 \\
(.075)\end{array}$ \\
\hline Agric. & $\begin{array}{r}-.047^{* *} \\
(.018)\end{array}$ & $\begin{array}{c}-.042^{*} \\
(.018)\end{array}$ & $\begin{array}{l}-.035^{*} \\
(.019)\end{array}$ & $\begin{array}{c}-.043^{* *} \\
(.019)\end{array}$ & $\begin{array}{c}-.039^{* *} \\
(.019)\end{array}$ & $\begin{array}{l}-.034^{*} \\
(.019)\end{array}$ & $\begin{array}{l}-.027 \\
(.021)\end{array}$ & $\begin{array}{c}.000 \\
(.004)\end{array}$ \\
\hline Imp. & $\begin{array}{l}.014^{*} \\
(.008)\end{array}$ & $\begin{array}{c}.014 \\
(.008)\end{array}$ & $\begin{array}{c}.012 \\
(.009)\end{array}$ & $\begin{array}{c}.014 \\
(.008)\end{array}$ & $\begin{array}{c}.013 \\
(.009)\end{array}$ & $\begin{array}{c}.012 \\
(.009)\end{array}$ & $\begin{array}{c}.007 \\
(.010)\end{array}$ & $\begin{array}{c}.001 \\
(.001)\end{array}$ \\
\hline Const. & $\begin{array}{l}13.4^{* *} \\
(5.48)\end{array}$ & $\begin{array}{l}13.4^{* *} \\
(5.32)\end{array}$ & $\begin{array}{l}13.1^{* *} \\
(5.07)\end{array}$ & $\begin{array}{l}10.8^{* *} \\
(4.82)\end{array}$ & $\begin{array}{l}10.5^{* *} \\
(4.78)\end{array}$ & $\begin{array}{l}10.0^{* *} \\
(4.69)\end{array}$ & $\begin{array}{c}7.68 \\
(5.37)\end{array}$ & $\begin{array}{l}-.250 \\
(.629)\end{array}$ \\
\hline Observ. & 1,684 & 1,603 & 1,521 & 1,684 & 1,603 & 1,521 & 1,231 & 1,727 \\
\hline Countries & 96 & 96 & 96 & 96 & 96 & 96 & 79 & 97 \\
\hline
\end{tabular}

Notes: The sample refers to 1990-2011. The dependent variable is revenue from consumption taxes in percent of GDP in columns (1)-(7) and a dummy variable for VAT in column (8). Agric. and Imp. are the values of agriculture and imports in percent of GDP. $\log G D P$ is the logarithm of per capita GDP. All columns include country- and year-fixed effects. In specifications (1)-(3), I(TA) refers to the date of entry into GATT/WTO. In these specifications, $\overline{I(T A)_{t}^{y+s}}$ equals one $s$ years prior to GATT/WTO membership and $I(T A)_{t-1}$ equals one for all years starting after the first year of GATT/WTO membership. In specifications (4)-(8), I(TA) refers to the date when a Memorandum on the foreign trade regime is submitted to the WTO. Thus, ${\overline{I(T A)_{t}}}_{t}^{y+s}$ is equal to one $s$ years prior to the start of the WTO negotiations marked by the submission of the Memorandum. I $(T A)_{t-1}$ in specifications (4)-(7) equals one for all years starting after the first year of WTO negotiations. Column (7) excludes the 17 contracting parties joining GATT between 1990 and 1994. Standard errors are clustered by country in all specifications. Asterisks denote significance at the $1 \%\left({ }^{* * *}\right), 5 \%\left({ }^{* *}\right)$, and $10 \%\left({ }^{*}\right)$ levels.

entry procedure was less involved, and it is hard to pinpoint a date before entry resembling the date of Memorandum submission. For this reason, column (7) excludes these countries. In this specification, the lead variables remain statistically insignificant. At the same time, however, the effect of the Memorandum submission increases in size and the long-run effect rises to $1.75 \%$. Column (8) employs a binary dependent variable reflecting whether a VAT is implemented. The significant positive effect in the period after Memorandum submission supports the view that trade liberalization triggers VAT adoption. The point estimate indicates that the probability to use a VAT rises by about 25 percentage points after Memorandum submission. 
Table 6: CONSUMPTION TAXES AND REVENUE SUBSTITUTION

\begin{tabular}{lccc}
\hline \hline & $(1)$ & $(2)$ & $(3)$ \\
\cline { 2 - 4 }$T^{I M P}$ & $-1.61^{* *}$ & $-1.50^{* *}$ & $-1.75^{* *}$ \\
$\log G D P$ & $(.670)$ & $(.606)$ & $(.792)$ \\
& $-.343^{*}$ & $-.606^{*}$ & $-2.21^{*}$ \\
Agric. & $.993)$ & $(1.02)$ & $(1.29)$ \\
& -.050 & -.053 & $-.090^{* *}$ \\
Imp. & $(.033)$ & $(.032)$ & $.067)$ \\
& .008 & .013 & .013 \\
Observ. & $.018)$ & $(.016)$ & $(.021)$ \\
Countries & 1,760 & 1,639 & 1,209 \\
F-Stat. & 96 & 87 & 67 \\
LM-Stat. & 5.95 & 5.60 & 4.29 \\
Wald-Stat. & 4.63 & 4.98 & 3.19 \\
\hline
\end{tabular}

Notes: The sample refers to 1990-2011. The dependent variable is revenue from consumption taxes in percent of GDP. Agric., Imp. are the values of agriculture and imports in percent of GDP. $\log G D P$ is the logarithm of per capita GDP. $T^{I M P}$ is revenue from import duties in percent of GDP. Column (2) excludes 9 WTO members in the sample that joined after 2011. Column (3) excludes the 29 countries that received loans from the IMF's PRGF Program. Columns (1)-(3) report instrumental variable estimates where revenues from import duties are treated as endogenous. The first-stage regression includes the WTO/GATT membership indicator $I(T A)$ as instrumental variable. Results for the first stage are provided in Table 2. All columns include country- and year-fixed effects. Standard errors are clustered by country in all specifications. Asterisks denote significance at the $1 \%\left({ }^{* * *}\right), 5 \%\left({ }^{* *}\right)$, and $10 \%\left({ }^{*}\right)$ levels. The bottom of the table reports statistics the F-Statistic of the excluded instrument. LM-Stat. reports the Kleibergen-Paap rank statistic, which is the Chi-sq(1) distributed statistic suggested by Anderson and Rubin.

Even if anticipation effects are ignored, the estimates of the effect of WTO membership on consumption tax revenues in the reduced-form specification of Table 4 point to a gain in consumption taxes that exceeds losses in import duties as reported in Table 2. An estimate of the substitution effect can be computed using the point estimate for losses from import duties, $\widehat{a}_{1}$, in column (2) of Table $2(-.731)$ and the reduced-form effect on consumption taxes, $\widehat{b}_{1}$, in column (2) of Table 4 (1.24). More specifically, the implied point estimate for the substitution effect in the structural equation (2), $\widehat{c}_{1}=\frac{\widehat{b}_{1}}{\widehat{a}_{1}}$, is -1.70 , indicating that every dollar of lost import duties is more than compensated for with $\$ 1.7$ of additional consumption taxes. As the estimated revenue gains tend to be larger once anticipation effects are taken into account, we consider this estimate to be a lower bound of the true treatment effect.

Results from the joint estimation of the system of equations (1) and (2) are provided in Table 6. The basic IV-estimate in column (1) supports an effective substitution of GATT/WTO induced changes in import duties with consumption tax revenues. Using the indicator of GATT/WTO membership $I(T A)$ as the single excluded instrumental variable, the structural equation (2) is ex- 
actly identified. The F-statistic reported at the bottom confirms the relevance of the GATT/WTO membership in the first-stage. The table also reports statistics for underidentification (LM-Test) and for weak identification (Wald-Test), which are significant at 5\% in all specifications, thus rejecting the hypotheses of a rank-deficit in the reduced from and of weak identification. Based on the point estimate, for every Dollar of lost import duties, consumption tax revenues increase by about $\$ 1.6$ with a $95 \%$ confidence interval between an effect of 29 cents and $\$ 2.9 .^{25}$ Column (2) shows that the results are robust to excluding WTO observers that joined the WTO after the estimation period. According to column (3), excluding countries that took part in IMF assistance programs has only a minor effect on the estimated degree of revenue substitution.

\section{Conclusions}

This paper empirically analyzes fiscal implications of trade liberalization policies. In particular, it considers the role of consumption taxes in recovering revenue losses from import duties. The question is especially pertinent to poor and least developed economies considering trade liberalization policies such as an accession to the World Trade Organization. In contrast to the existing literature, which has attempted to address revenue substitution by analyzing the relationship between revenue sources, we identify trade liberalization policies directly. To this end we refer to countries' membership in the WTO. We argue and document that entry into the late-Uruguay GATT or its successor, the WTO, is associated with trade liberalization commitments that lead to revenue losses and trigger tax reforms. Using a large panel of developing and transitional economies for the period 1990-2011, the paper investigates how revenues from import duties and consumption taxes evolve over the course of accession negotiations and WTO entry.

Employing difference-in-difference regressions as well as a synthetic control group method, our results reveal a negative relationship between WTO membership and import duties. On average, revenue losses from import duties amount to about $0.5 \%$ to $1 \%$ of the WTO members' GDP. Yet, further analysis shows that revenue from consumption taxes increases significantly around WTO accession. On the whole, our findings indicate that countries joining the WTO have successfully substituted import duties with consumption taxes. Our results further demonstrate that the tim-

\footnotetext{
${ }^{25}$ Note that this number differs slightly from the point estimate implied by the reduced form estimates. This is due to differences in the estimation sample for WTO effects on import duties and consumption taxes. The firststage regression in the IV estimation uses a reduced set of observations as consumption tax revenues are not always available.
} 
ing of revenue losses from import duties and revenue gains from consumption tax reform is not simultaneous. In particular, cuts in tariffs mostly occur at the time when trade liberalization commitments are made or later, but not earlier. Consumption tax revenue, however, responds ahead of such commitments. The adoption of VAT is also found to take place usually before entry.

However, no effects are found before the date a Memorandum on the foreign trade regime is submitted to the WTO, which marks the beginning of proper accession negotiations. This suggests that the pre-membership effects in the revenues from consumption taxes are not indicative of reverse causation, but rather reflect the anticipation of revenue losses as countries ensure continuous funding of the budget despite substantial revenue losses expected from trade liberalization. In the presence of such anticipation effects, the relationship between consumption tax revenue and trade taxes as studied in the existing empirical literature only captures a part of the total revenue substitution effect. As concerns about revenue losses are of particular importance to countries where import duties make up a larger share of public funds, this could explain why the previous literature has found weaker substitution effects for least developed economies.

The empirical findings also point to different revenue effects among accession countries. In particular, the revenue implications of GATT/WTO accession are found to depend on whether countries participate in IMF programs for structural adjustment, poverty reduction and growth. Revenue losses from import duties tend to be larger and consumption tax revenue show a stronger increase if participating countries are excluded. Since unilateral trade liberalization measures as well as tax reforms are typical components of IMF conditionalities for the release of funds, this may reflect a lower need for revenue substitution in these countries upon GATT/WTO accession. 
Table A-1: COUNTRIES IN THE SAMPLE

\begin{tabular}{|c|c|c|c|c|c|c|c|}
\hline Africa & GATT & VAT & WTO & Europe & GATT & VAT & WTO \\
\hline Algeria ${ }^{\ddagger}$ & - & 1992 & - & Albania & - & 1996 & 2000 \\
\hline $\operatorname{Benin}(\mathrm{LDC})^{*}$ & 1963 & 1991 & 1996 & Belarus $^{\ddagger}$ & - & 1991 & - \\
\hline Botswana* & 1987 & 2002 & 1995 & Bulgaria & - & 1994 & 1996 \\
\hline Burkina Faso (LDC) ${ }^{*}$ & 1963 & 1993 & 1995 & Croatia & - & 1998 & 2000 \\
\hline Cameroon* & 1963 & 1999 & 1995 & Cyprus* & 1963 & 1992 & 1995 \\
\hline Cape Verde & - & 2004 & 2008 & Czech Republic & 1993 & 1993 & 1995 \\
\hline CAR (LDC)* & 1963 & 2001 & 1995 & Estonia & - & 1991 & 1999 \\
\hline Chad (LDC)* & 1963 & 2000 & 1996 & Finland & 1950 & 1994 & 1995 \\
\hline Comoros $(\mathrm{LDC})^{\ddagger}$ & - & - & - & Iceland & 1968 & 1990 & 1995 \\
\hline Egypt & 1970 & - & 1995 & Latvia & - & 1995 & 1999 \\
\hline Equatorial Guinea (LDC) ${ }^{\ddagger}$ & - & 2005 & - & Lithuania & - & 1994 & 2001 \\
\hline Ethiopia $(\mathrm{LDC})^{\ddagger}$ & - & 2003 & - & Malta* & 1964 & 1995 & 1995 \\
\hline Gabon* & 1963 & 1995 & 1995 & Montenegro & - & 2003 & - \\
\hline Gambia (LDC)* & 1965 & - & 1996 & Poland & 1967 & 1993 & 1995 \\
\hline Ghana* & 1957 & 1995 & 1995 & Romania & 1971 & 1993 & 1995 \\
\hline Guinea (LDC)* & 1994 & 1996 & 1995 & Serbia $^{\ddagger}$ & - & 2005 & - \\
\hline Kenya $(\mathrm{LDC})^{*}$ & 1964 & 1990 & 1995 & Slovakia & 1993 & 1993 & 1995 \\
\hline Lesotho (LDC)* & 1988 & 2003 & 1995 & Slovenia & 1994 & 1999 & 1995 \\
\hline Madagascar $(\mathrm{LDC})^{*}$ & 1963 & 1994 & 1995 & Switzerland & 1966 & 1995 & 1995 \\
\hline Mali $(\mathrm{LDC})^{*}$ & 1993 & 1991 & 1995 & Ukraine & - & 1992 & 2008 \\
\hline Mauritania (LDC)* & 1963 & 1995 & 1995 & & & & \\
\hline Mauritius* & 1970 & 1998 & 1995 & Caribbean and Oceania & & & \\
\hline Mozambique (LDC)* & 1992 & 1999 & 1995 & & & & \\
\hline S. T. and Principe (LDC $)^{\ddagger}$ & - & - & - & Antigua and Barbuda* & 1987 & 2007 & 1995 \\
\hline Seychelles & - & - & - & Australia & 1948 & 2000 & 1995 \\
\hline South Africa & 1948 & 1991 & 1995 & Bahamas $^{\ddagger}$ & - & - & - \\
\hline Sudan $(\text { LDC })^{\ddagger}$ & - & 2000 & - & Barbados* & 1967 & 1997 & 1995 \\
\hline Tanzania $(\mathrm{LDC})^{*}$ & 1961 & 1998 & 1995 & Dominica* & 1993 & 2006 & 1995 \\
\hline Uganda $(\mathrm{LDC})^{*}$ & 1962 & 1996 & 1995 & DominicanRepublic & 1950 & 1992 & 1995 \\
\hline \multirow[t]{2}{*}{ Zambia $(\mathrm{LDC})^{*}$} & 1982 & 1995 & 1995 & Fiji* $^{*}$ & 1993 & 1992 & 1996 \\
\hline & & & & Grenada* & 1994 & 1987 & 1996 \\
\hline (Eur)Asia & & & & Jamaica* & 1963 & 1991 & 1995 \\
\hline Armenia & - & 1993 & 2003 & Micronesia & - & - & - \\
\hline Azerbaijan ${ }^{\ddagger}$ & - & 1992 & - & Palau & - & - & - \\
\hline Bangladesh (LDC) & 1972 & 1991 & 1995 & Papua New Guinea* & 1994 & 1999 & 1996 \\
\hline Bhutan $(\mathrm{LDC})^{\ddagger}$ & - & - & - & Saint Kitts and Nevis & 1994 & 2011 & 1996 \\
\hline Cambodia (LDC) & - & 1999 & 2004 & St. V. and the Grenadines & 1993 & 2007 & 1995 \\
\hline $\operatorname{Iran}^{\ddagger}$ & - & 2008 & - & Samoa & - & 1994 & - \\
\hline Jordan & - & 2001 & 2000 & Solomon Islands (LDC)* & 1994 & - & 1996 \\
\hline Kazakhstan & - & 1991 & - & Tonga & - & 2005 & 2007 \\
\hline Laos (LDC) & - & 2010 & - & Trinidad and Tobago* & 1962 & 1990 & 1995 \\
\hline Lebanon $^{\ddagger}$ & - & 2002 & - & Vanuatu (LDC) & - & 1998 & - \\
\hline Malaysia* & 1957 & - & 1995 & & & & \\
\hline Mongolia & - & 1998 & 1997 & & & & \\
\hline Pakistan & 1948 & 1998 & 1995 & America & & & \\
\hline Russia & - & 1991 & - & & & & \\
\hline Singapore* & 1973 & 1994 & 1995 & Canada & 1948 & 1991 & 1995 \\
\hline Sri Lanka & 1948 & 1998 & 1995 & El Salvador & 1991 & 1992 & 1995 \\
\hline Syria ${ }^{\ddagger}$ & - & - & - & Guatemala & 1991 & 1992 & 1995 \\
\hline Tajikistan & - & 1992 & - & Paraguay & 1994 & 1992 & 1995 \\
\hline Thailand & 1982 & 1992 & 1995 & Peru & 1951 & 1991 & 1995 \\
\hline Vietnam & - & 1997 & 2007 & Suriname* & 1978 & - & 1995 \\
\hline Yemen (LDC) & - & - & - & Venezuela & 1990 & 1993 & 1995 \\
\hline
\end{tabular}

Notes: LDC stands for Least Developed Country following the UN classification. GATT, WTO, and VAT denote membership years in GATT and WTO and the year of VAT introduction, if any. Countries with asterisk acceded to GATT under Article XXVI: 5(c). Countries marked with $\ddagger$ are current WTO Observers. Countries in bold received funds from the IMF under the PRGF program. The table conveys VAT implementation information and WTO status as of 2011. 
Table A-2: VARIABLES' DEFINITIONS AND SOURCES

\begin{tabular}{|c|c|}
\hline Cons.taxes & $\begin{array}{l}\text { General consumption tax revenue collected domestically and at the border. It } \\
\text { reflects collections from the indirect tax structure prevalent in a given country before } \\
\text { VAT introduction, e.g. retail sales tax, turnover tax (if any), and is VAT revenue } \\
\text { thereafter. Source: IMF Statistical Appendices and Recent Development Reports } \\
\text { accessed through IMF eLibrary, National Statistical Offices and Central Banks, } \\
\text { Ministries of Finance, IMF Government Finance Statistics, OECD, Eurostat and } \\
\text { various country-specific publications. }\end{array}$ \\
\hline Imp.duties & $\begin{array}{l}\text { Revenue from import duties, excluding indirect tax collected at the border. Source: } \\
\text { IMF Statistical Appendices and Recent Development Reports accessed through IMF } \\
\text { eLibrary, National Statistical Offices and Central Banks, Ministries of Finance, } \\
\text { IMF Government Finance Statistics, OECD, Eurostat and various country-specific } \\
\text { publications. }\end{array}$ \\
\hline Import & $\begin{array}{l}\text { Imports of goods and services. Source: UN National Accounts Main Aggregates } \\
\text { Database. }\end{array}$ \\
\hline$G D P$ & $\begin{array}{l}\text { Gross domestic product at current prices in national currencies. Source: UN } \\
\text { National Accounts Main Aggregates Database. }\end{array}$ \\
\hline GDPp.c. & $\begin{array}{l}\text { GDP per capita, (constant } 2005 \text { US\$). Source: World Bank Development } \\
\text { Indicators; UN National Accounts Main Aggregates Database. }\end{array}$ \\
\hline Agric & $\begin{array}{l}\text { Agriculture, value added as a percent of GDP. Source: World Bank Development } \\
\text { Indicators; UN National Accounts Main Aggregates Database. }\end{array}$ \\
\hline$I(T A)$ & $\begin{array}{l}\text { A dummy variable equal to } 1 \text { if a country is a member of GATT/WTO, and } 0 \\
\text { otherwise. If a country became a GATT contracting party before becoming a WTO } \\
\text { member, the relevant year is the GATT membership year. For example, since Chad } \\
\text { became a GATT contracting party in } 1963, I(T A) \text { equals one for all years Chad } \\
\text { appears in the sample, even though the country joined the WTO in } 1996 \text {. For non- } \\
\text { GATT members, } I(T A) \text { equals one based on the year of WTO membership. For } \\
\text { the year of membership, the variable equals the number of days after GATT/WTO } \\
\text { membership divided by the total number of days in the year. For example, if } \\
\text { a country joined on } 29 \text { January } 2007, I(T A) \text { equals } 0.92054 \text { for } 2007 \text { and } 1 \text { for } \\
\text { subsequent years. In section } 6 \text { an alternative indicator is used that refers to the } \\
\text { date of Memorandum submission. This indicator is constructed in a similar fashion. } \\
\text { For GATT/WTO members it is set equal to unity. Source: The World Trade } \\
\text { Organisation and authors' calculations. }\end{array}$ \\
\hline$I M F$ & $\begin{array}{l}\text { A dummy variable equal to one if a country has obtained loans through IMF's } \\
\text { Poverty Reduction and Growth Facility. Source: International Monetary Fund. }\end{array}$ \\
\hline$I(V A T)$ & $\begin{array}{l}\text { A dummy variable equal to one if a country has a full-fledged VAT, i.e. VAT is } \\
\text { levied on all stages of production and on both goods and services. For the exact } \\
\text { year of adoption, } I(V A T) \text { equals the number of days after VAT's implementation } \\
\text { divided by the total number of days in the year. Source: Ernst \& Young Worldwide } \\
\text { VAT, GST and Sales Tax Guides for various years and various country-specific } \\
\text { publications. }\end{array}$ \\
\hline
\end{tabular}


Table A-3: DESCRIPTIVE STATISTICS BY REGION AND TIME-PERIOD

\begin{tabular}{|c|c|c|c|c|c|c|c|}
\hline & $\begin{array}{l}\text { 1990-1993 } \\
\text { Mean }\end{array}$ & $\begin{array}{c}\text { 1994-1997 } \\
\text { Mean }\end{array}$ & $\begin{array}{c}\text { 1998-2001 } \\
\text { Mean }\end{array}$ & $\begin{array}{c}\text { 2002-2005 } \\
\text { Mean }\end{array}$ & $\begin{array}{c}\text { 2006-2009 } \\
\text { Mean }\end{array}$ & $\begin{array}{c}2010-2011 \\
\text { Mean }\end{array}$ & $\mathrm{N}$ \\
\hline & \multicolumn{7}{|c|}{ Full sample } \\
\hline Imp.duties & $3.31(3.49)$ & $2.88(3.28)$ & $2.39(2.67)$ & $2.18(2.52)$ & $2.21(3.63)$ & $1.80(2.87)$ & 1842 \\
\hline Cons.taxes & $3.72(2.76)$ & $4.41(2.64)$ & $4.74(2.35)$ & $5.36(2.51)$ & $6.18(2.72)$ & $6.30(2.59)$ & 1808 \\
\hline Agric & $21.32(14.89)$ & $19.75(14.71)$ & $17.49(13.49)$ & $15.46(12.70)$ & $14.23(12.52)$ & $14.03(12.35)$ & 2107 \\
\hline Import & $44.63(25.07)$ & $46.82(25.33)$ & $47.85(25.47)$ & $48.69(24.20)$ & $51.40(24.87)$ & $50.76(24.18)$ & 2130 \\
\hline GDPp.c. & $4873(8150)$ & $5067(8413)$ & $5637(9378)$ & $6259(10110)$ & 7129 (11091) & $7213(11005)$ & 2117 \\
\hline$I(T A)$ & $.457(.494)$ & $.592(.490)$ & $.643(.476)$ & $.691(.461)$ & $.722(.445)$ & $.742(.438)$ & 2134 \\
\hline \multirow[t]{2}{*}{$I(V A T)$} & $.176(.368)$ & $.446(.490)$ & $.630(.475)$ & $.742(.435)$ & $.811(.389)$ & $.846(.359)$ & 2134 \\
\hline & \multicolumn{7}{|c|}{ Africa } \\
\hline Imp.duties & $3.93(4.90)$ & $3.59(4.88)$ & $3.18(4.09)$ & $3.16(3.92)$ & $3.90(6.50)$ & $3.46(5.40)$ & 536 \\
\hline Cons.taxes & $2.61(1.70)$ & $3.11(1.76)$ & $3.64(1.46)$ & $4.55(1.97)$ & $5.41(2.05)$ & $5.52(1.87)$ & 532 \\
\hline Agric & $28.97(15.81)$ & $28.08(15.31)$ & $25.93(14.58)$ & $23.97(14.41)$ & $22.77(15.08)$ & $22.29(14.87)$ & 660 \\
\hline Import & $37.91(25.16)$ & $40.72(27.60)$ & $41.68(29.70)$ & $40.83(23.75)$ & $44.01(22.75)$ & $44.60(22.86)$ & 659 \\
\hline GDPp.c. & $1422(2217)$ & $1508(2331)$ & $1730(2574)$ & $1978(2911)$ & $2268(3400)$ & $2357(3467)$ & 660 \\
\hline$I(T A)$ & $.653(.475)$ & $.725(.447)$ & $.733(.444)$ & $.733(.444)$ & $.745(.435)$ & $.766(.426)$ & 660 \\
\hline$I(V A T)$ & \multicolumn{7}{|c|}{ America } \\
\hline Imp.duties & $1.58(.606)$ & $1.95(1.06)$ & $1.64(1.04)$ & $1.39(.841)$ & $1.05(.645)$ & $.922(.663)$ & 152 \\
\hline Cons.taxes & $3.15(1.44)$ & $4.57(.941)$ & $4.68(.854)$ & $5.04(.904)$ & $5.43(.990)$ & $5.59(1.21)$ & 143 \\
\hline Agric & $11.41(5.95)$ & $11.61(5.73)$ & $9.76(4.64)$ & $8.97(5.42)$ & $9.93(5.86)$ & $10.16(6.37)$ & 154 \\
\hline Import & $31.18(11.73)$ & $32.86(13.78)$ & $33.52(10.72)$ & $34.34(11.36)$ & $37.49(12.04)$ & $35.99(12.31)$ & 154 \\
\hline GDPp.c. & $6135(8861)$ & $6478(9401)$ & $7011(10641)$ & 7442 (11513) & $8114(11936)$ & $8292(12164)$ & 154 \\
\hline$I(T A)$ & $.717(.434)$ & $.999(.003)$ & $1(0)$ & $1(0)$ & $1(0)$ & $1(0)$ & 154 \\
\hline$I(V A T)$ & $.357(.442)$ & $.857(.356)$ & $.857(.356)$ & $\begin{array}{l}.857(.356) \\
\text { Asia }\end{array}$ & $.857(.356)$ & $.857(.363)$ & 154 \\
\hline Imp.duties & $2.75(2.19)$ & $2.37(1.78)$ & $1.79(1.13)$ & $1.60(.837)$ & $1.50(.917)$ & $1.29(.932)$ & 386 \\
\hline Cons.taxes & $3.34(2.77)$ & $3.23(2.26)$ & $3.54(1.95)$ & $3.96(2.35)$ & $4.16(2.52)$ & $4.48(2.67)$ & 381 \\
\hline Agric & $25.54(14.05)$ & $23.38(14.37)$ & $20.08(12.50)$ & $16.42(10.08)$ & $14.64(9.51)$ & $14.44(9.74)$ & 452 \\
\hline Import & $49.22(33.13)$ & $53.28(34.14)$ & $52.10(32.50)$ & $56.14(35.82)$ & $55.81(38.14)$ & $53.59(36.42)$ & 462 \\
\hline GDPp.c. & $2248(3742)$ & $2462(4630)$ & $2620(4930)$ & $3068(5699)$ & $3755(6654)$ & $4224(7555)$ & 458 \\
\hline$I(T A)$ & $.285(.454)$ & $.296(.458)$ & $.353(.478)$ & $.429(.494)$ & $.511(.502)$ & $.523(.505)$ & 462 \\
\hline \multirow[t]{2}{*}{$I(V A T)$} & $.158(.355)$ & $.377(.485)$ & $.598(.487)$ & $.713(.453)$ & $.729(.444)$ & $.809(.397)$ & 462 \\
\hline & \multicolumn{7}{|c|}{ Caribbean and Oceania } \\
\hline Imp.duties & $4.28(2.68)$ & $4.06(2.35)$ & $3.57(1.71)$ & $3.33(1.77)$ & $3.24(1.89)$ & $2.60(1.34)$ & 401 \\
\hline Cons.taxes & $4.25(2.92)$ & $4.93(2.71)$ & $5.08(2.38)$ & $5.64(2.50)$ & $6.52(2.39)$ & $6.86(2.61)$ & 377 \\
\hline Agric & $16.06(11.96)$ & $14.22(11.47)$ & $12.96(11.08)$ & $12.01(11.43)$ & $10.85(10.02)$ & $10.77(9.85)$ & 416 \\
\hline Import & $54.38(16.02)$ & $53.48(13.59)$ & $54.59(14.47)$ & $52.36(12.90)$ & $55.41(13.62)$ & $53.77(13.76)$ & 418 \\
\hline GDPp.c. & $6310(6531)$ & $6690(6790)$ & $7367(7635)$ & $7911(8121)$ & $8613(8620)$ & $8342(8535)$ & 417 \\
\hline$I(T A)$ & $.334(.467)$ & $.654(.474)$ & $.684(.467)$ & $.684(.467)$ & $.716(.450)$ & $.736(.446)$ & 418 \\
\hline \multirow[t]{2}{*}{$I(V A T)$} & $.187(.382)$ & $.289(.456)$ & $.413(.485)$ & $.476(.500)$ & $.650(.473)$ & $.743(.436)$ & 418 \\
\hline & \multicolumn{7}{|c|}{ Europe } \\
\hline Imp.duties & $2.15(2.14)$ & $1.41(1.14)$ & $.842(.733)$ & $.637(.602)$ & $.595(.709)$ & $.471(.598)$ & 382 \\
\hline Cons.taxes & $7.57(3.99)$ & $7.04(2.36)$ & $7.21(2.11)$ & $7.85(1.90)$ & $8.69(2.18)$ & $8.42(1.76)$ & 386 \\
\hline Agric & $13.27(10.64)$ & $11.01(10.13)$ & $8.90(7.12)$ & $7.22(5.51)$ & $5.70(4.41)$ & $5.69(4.55)$ & 425 \\
\hline Import & $45.37(20.70)$ & $47.77(17.80)$ & $51.26(17.18)$ & $54.19(14.16)$ & $58.93(15.83)$ & $59.22(15.80)$ & 437 \\
\hline GDPp.c. & 11699 & 11426 & 12541 & 14049 & 16123 & 16036 & 428 \\
\hline & $(13280)$ & $(13375)$ & $(14719)$ & $(15580)$ & $(16892)$ & $(16508)$ & \\
\hline$I(T A)$ & $.367(.479)$ & $.503(.500)$ & $.650(.470)$ & $.800(.402)$ & $.820(.382)$ & $.85(.361)$ & 440 \\
\hline$I(V A T)$ & $.200(.393)$ & $.702(.444)$ & $.862(.337)$ & $.946(.220)$ & $1(0)$ & $1(0)$ & 440 \\
\hline
\end{tabular}

Note: The table depicts summary statistics for the full sample as well as statistics disaggregated by five major geographical regions: Africa, America, Asia, Europe, and the Caribbean and Oceania. Imp.duties, Cons.taxes, Agric, Import are import duties, consumption taxes, agriculture, and imports, respectively, all expressed in terms of percentage of GDP. GDPp.c. is GDP per capita. $I(T A)$ is a dummy variable reflecting the time of membership in GATT/WTO. $I(V A T)$ is a dummy variable, which equals one when a country implements full-fledged VAT. Standard errors are in parentheses. 


\section{A.2 Revenue Developments}

Figure A-1 shows the development of import duties scaled by GDP for the new WTO members, the 1990-1994 GATT signatories, the pre-1990 GATT contracting parties and the non-members. There is a pronounced decline in import duties, with the strongest reduction observed for the new WTO members and the 1990-1994 GATT parties. While in 1990 the new WTO members and the 1990-1994 GATT signatories collected the highest revenues from import duties, in 2011 they report the lowest figures among all countries. Non-members collect the highest amount of import duties in percent of GDP, although some decline is observed since 2008. Figure A-2 displays trends in consumption tax revenues for identical country groups. All countries experience revenue growth. At the end of the observation period, consumption tax revenues are highest among the new WTO members and the 1990-1994 GATT signatories.

\section{A.3 Synthetic Control Group Estimation}

As noted in the paper, an alternative approach to estimate the treatment effects from GATT/WTO entry that provides valid empirical estimates even if common shocks exert differential effects among subgroups of the population is the synthetic control group method (SCG). This method is pioneered by Abadie and Gardeazabal (2003) and later applied in Abadie et al. (2010, 2015), for example. ${ }^{26}$ The SCG approach has been used in the comparative analysis of policies using aggregate data, where unobservable characteristics exert time-varying effects. Recently, Billmeier and Nannicini (2013) applied the method to study the effect of economic liberalization policies on GDP in various regions of the world. ${ }^{27}$

In the context of import duties the method generalizes the basic regression equation (1) by assuming that the residuals follow

$$
\epsilon_{i, t}=\lambda_{t} \mu_{i}+\phi_{i, t}
$$

\footnotetext{
26 Abadie, A., Diamond, A., Hainmueller, J., 2010. Synthetic control methods for comparative case studies: estimating the effect of California's tobacco control program. Journal of the American Statistical Association 105 (490), 493-505. Abadie, A., Diamond, A., Hainmueller, J., 2015. Comparative politics and the synthetic control method. American Journal of Political Science 59 (2), 495-510.

27 Billmeier, A., Nannicini, T., 2013. Assessing economic liberalization episodes: a synthetic control approach. Review of Economics and Statistics 95 (3), 983-1001.
} 
Figure A-1: IMPORT DUTIES 1990-2011

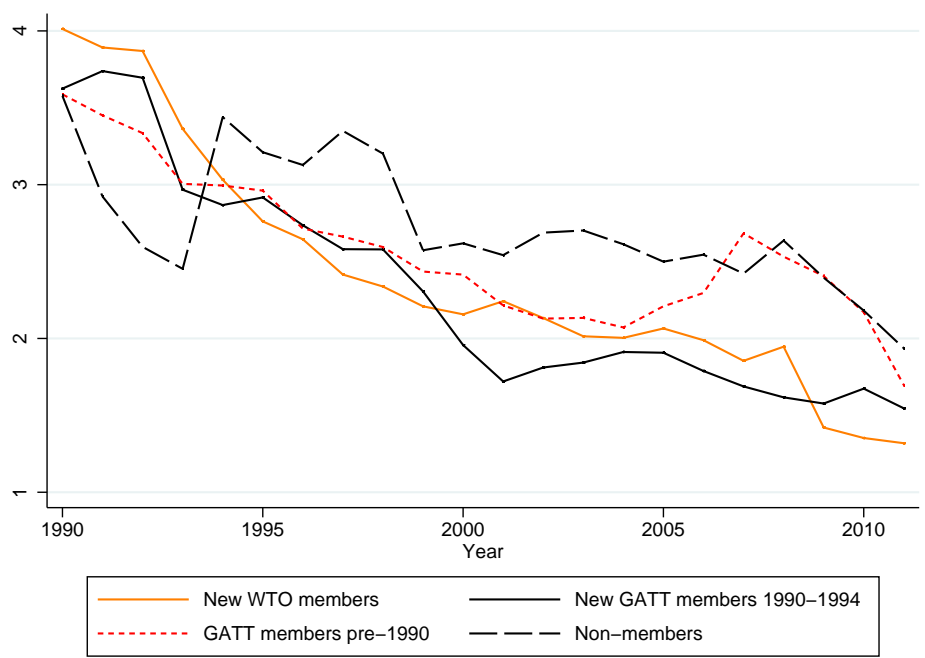

Note: The figure depicts the evolution of import duties in percent of GDP from 1990 to 2011 for four separate country groups: New WTO members, 1990-1994 GATT signatories, pre-1990 GATT contracting parties and non-members.

Figure A-2: CONSUMPTION TAX REVENUES 1990-2011

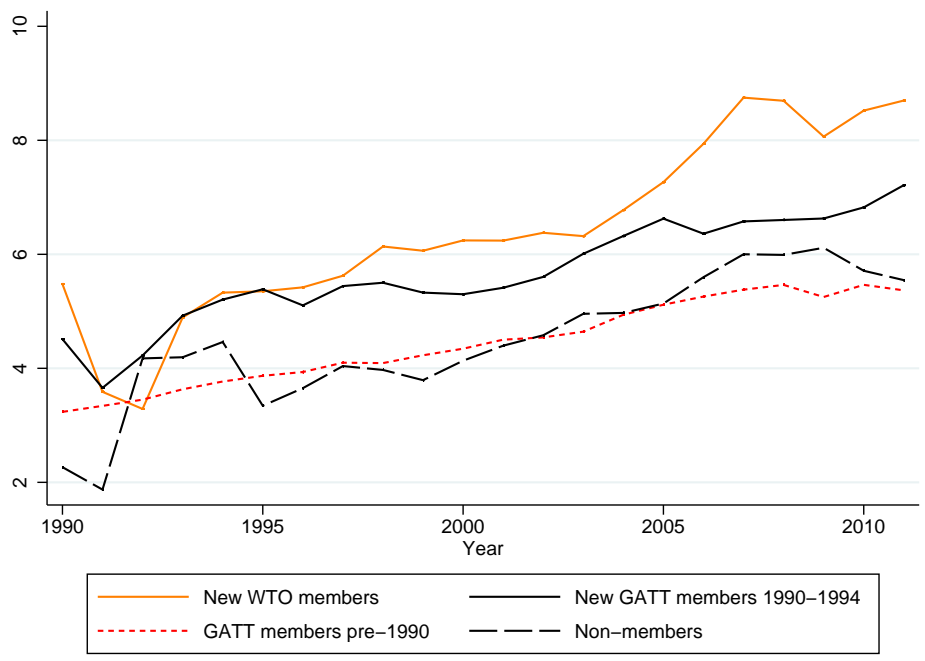

Note: The figure depicts the evolution of consumption taxes in percent of GDP from 1990 to 2011 for four separate country groups: New WTO members, 1990-1994 GATT signatories, pre-1990 GATT contracting parties and non-members. 
where $\phi_{i, t}$ is a random shock for each individual country. $\lambda_{t}$ is a common shock, while $\mu_{i}$ is a country-specific parameter. To determine treatment effects in this more general setting, Abadie et al. (2010) show that one can construct a weighted average of non-treated observations to produce a counterfactual series, i.e. a synthetic control group. The weights are chosen to minimize the difference between the pre-intervention characteristics of the treated and non-treated observations. The SCG estimator is then the difference between the post-intervention values of the treated country and the synthetic control (Abadie et al., 2015). ${ }^{28}$

The results below consider revenue outcomes over the first three years of WTO membership. For every country acceding to the WTO, we define a pool of countries, which did not join the organization during the observation period, to serve as its potential control group. To enlarge the set of observations in the group of non-treated countries, we include countries that became members later, i.e. in a period that is beyond the time window used to assess the treatment effect.

Comparison between treated observations (members) and non-treated observations (non-members) requires a full set of non-missing data for treated as well as for non-treated countries. For this reason, we could implement the approach for a limited number of countries. While including countries that acceded to the WTO in later years in the potential set of controls increases the set, it does not work for those treated countries that acceded to the WTO close to the end of the observation period. As a result we focus only on 9 treated countries. ${ }^{29}$ In all cases, we employ the same set of variables to determine the weights, i.e. the basic determinants of import duties as in the regressions of the paper. To capture further differences, we augmented the list of variables with an indicator for country size, dummies for some country groups and a dummy for participation in the IMF's SAF and PRGF programs. Note that due to the use of fixed-effects, these indicators are not included in the regression analysis of Table 2 .

While the approach is applicable to settings with a limited cross-sectional dimension, there is no straightforward test for the significance of the treatment effect. Therefore, we follow Abadie et al. (2010), and run a set of counterfactual regressions. The latter were generated on the false assumption of WTO accession of countries in the set of "donors", i.e. those countries that did not join the WTO in the analyzed period and serve as a potential reference point. Comparing these results with the analysis of actual WTO accessions, allows us to assess whether our findings differ

\footnotetext{
${ }^{28}$ In order to implement the SCG estimator, we employ STATA's synth command.

${ }^{29}$ We also dropped countries for which the SCG procedure yielded a single comparison unit. As pointed out by Abadie et al. (2015), a single untreated unit rarely provides a good fit of the pre-treatment path, which was corroborated by our results.
} 
from or are within the range of a set of random results.

Figure A-3 depicts the estimation results graphically by plotting the estimate of the treatment effect versus a set of "placebo" treatments. More specifically, the figure reports the difference in the revenue development between a treated country and its synthetic control in the actual case and in a set of counterfactual estimations. Without exception, in the periods after accession we see that revenues from import duties decline relative to the synthetic control group. The scale of the effect differs greatly across countries: In some cases the gap in revenues between members and controls amounts to a full percentage point of GDP or more (Albania, Bulgaria, Cambodia, Croatia, Mongolia). In other countries such as the Baltics (Latvia, Lithuania), the effects are minor but their pre-accession duties were also small. It turns out that in all countries where large treatment effects are found, the estimated revenue decline is stronger than in most of the placebo regressions. While the developments in the Baltics and Armenia also point to a decline in import duties after their WTO accession, in these cases, the effects are only within the range of the placebo treatments. Table A-4 provides means of covariates and outcomes for the respective country and its synthetic control group. The average difference between import duties of treated countries and their synthetic control groups amounts to -0.27 . While this points to a smaller decline compared with the results in Table 2 in the paper, it should be noted that the 9 countries included in the analysis also report lower import duties before the treatment. The average import duty revenue of the treated countries in the pre-treatment period is only $1.84 \%$ of GDP, whilst the total sample average is $3.31 \%$ of GDP in the period 1990-1993 (see Table A-3).

Next, we apply the SCG method to analyze consumption taxes. In this case the random disturbance $\eta_{i, t}$ in equation (3) of the paper is decomposed

$$
\eta_{i, t}=\kappa_{t} \nu_{i}+\varphi_{i, t}
$$

where $\varphi_{i, t}$ is a random shocks for each individual country, $\kappa_{t}$ is a common shock, and $\nu_{i}$ is a country-specific parameter. Given the presence of anticipation effects with regard to membership, the analysis focuses on the date of Memorandum submission rather than on the date of entry. Since the date of the Memorandum submission is observed only for a subset of countries, we were able to obtain results only for six countries.

Figure A-4 depicts the estimation results graphically. In four countries (Albania, Cambodia, Cape Verde and Jordan), strong increases in consumption tax revenues relative to the synthetic control 
groups can be observed around the Memorandum date. Also the revenue development in Vietnam points to a revenue increase. However, for Tonga the treatment effect turns out to be the opposite. As before, we explored the significance of the treatment effects by running "placebo" treatments. In three cases the estimated treatment effects are larger than the range of effects obtained for the placebo treatments. For the other countries, including Tonga, the effects found are within this range.

Outcome means are presented in Table A-5. After treatment, the average difference between consumption tax revenues of treated countries and their synthetic control groups amounts to $0.48 \%$ of GDP. As in the case of import duties this effect is smaller than the effect obtained from the regression analysis. At the same time, however, the average revenue increase in consumption taxes exceeds the average loss of import duties obtained using the SCG method above. For two countries, Cambodia and Albania, the SCG analysis provides estimates for the effects on both import duties and consumption taxes. Also in these cases the estimates indicate larger gains in consumption tax revenues than losses in import duties. 


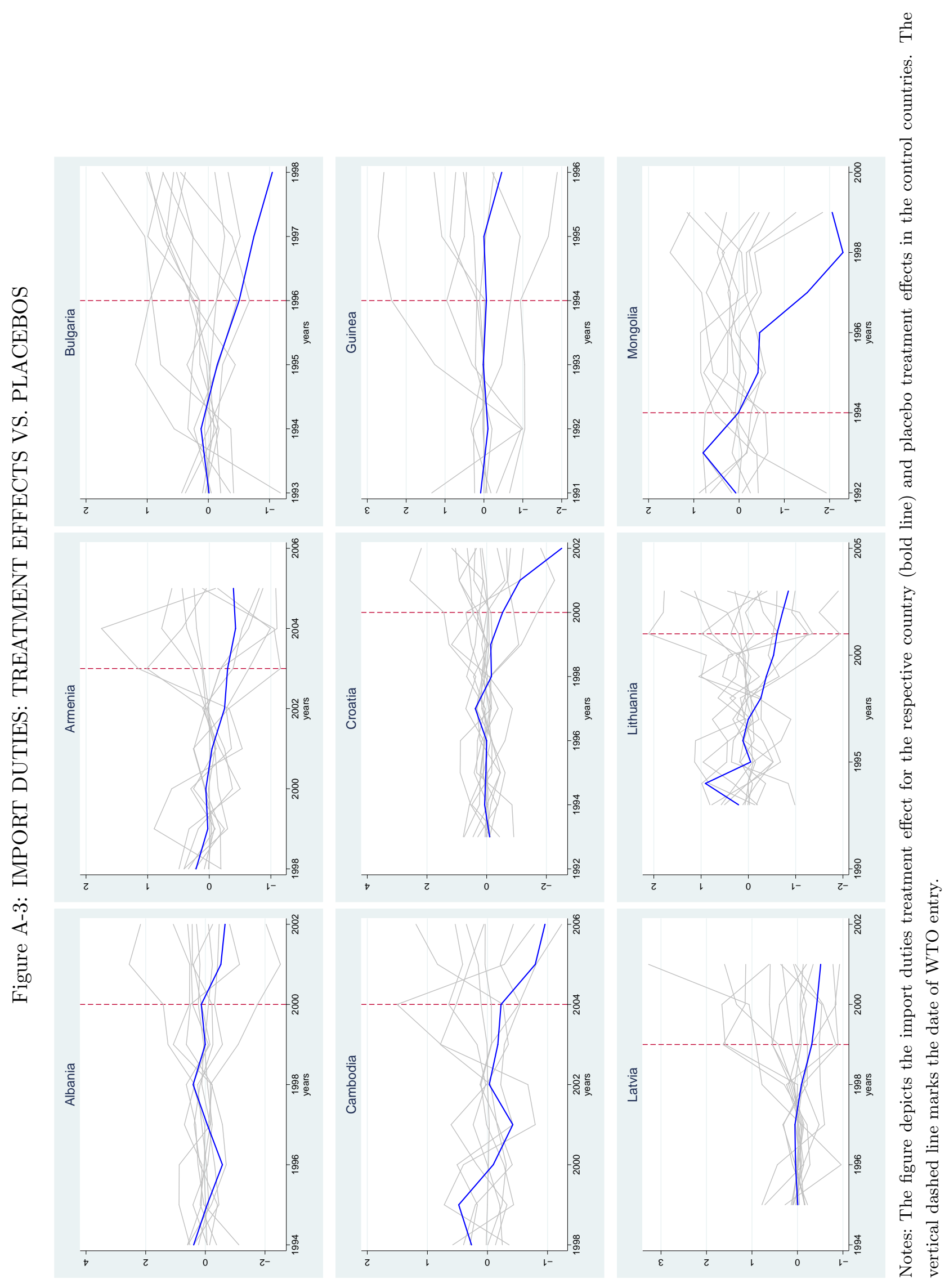




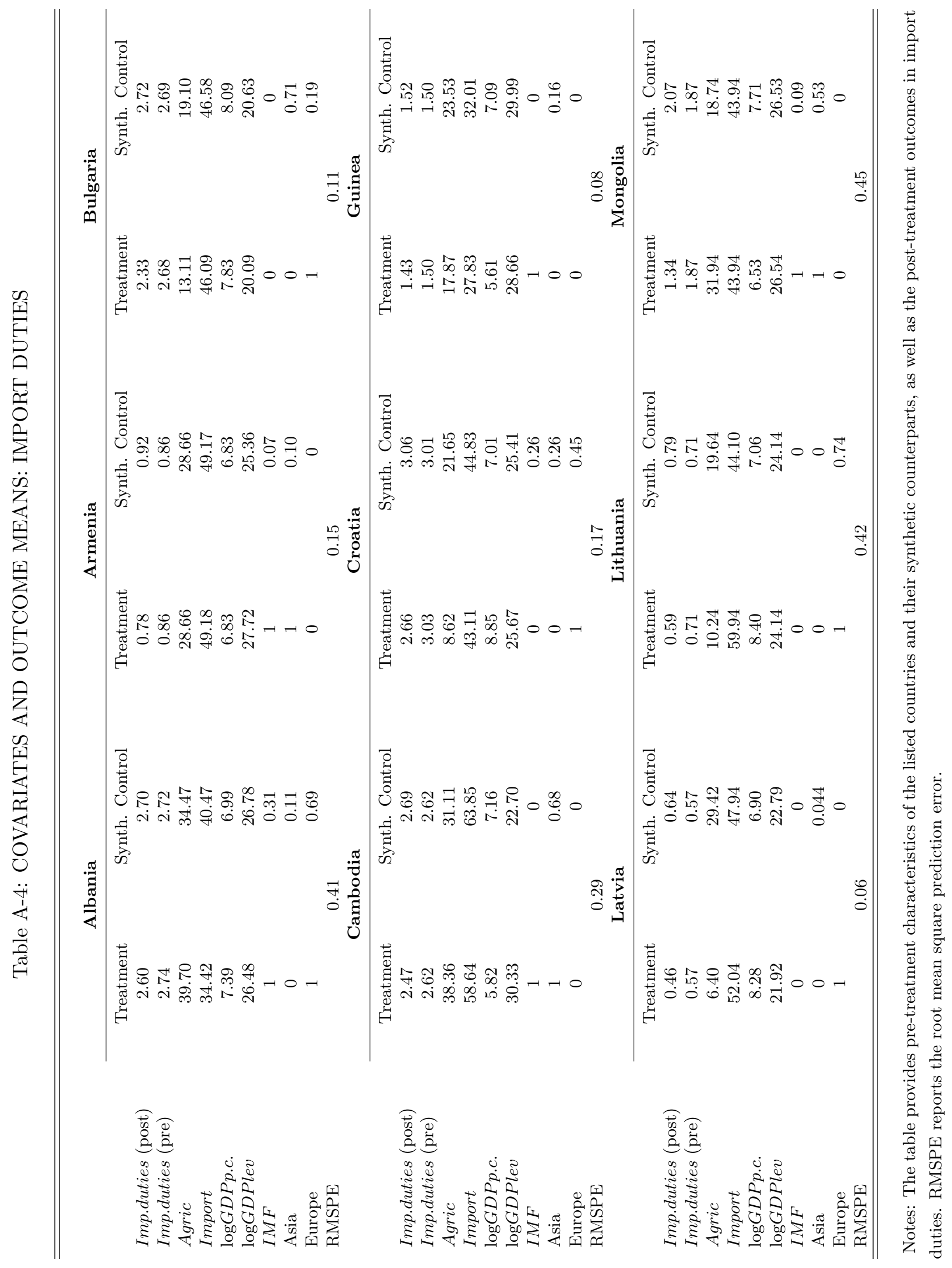


Figure A-4: CONSUMPTION TAXES: TREATMENT EFFECTS VS. PLACEBOS
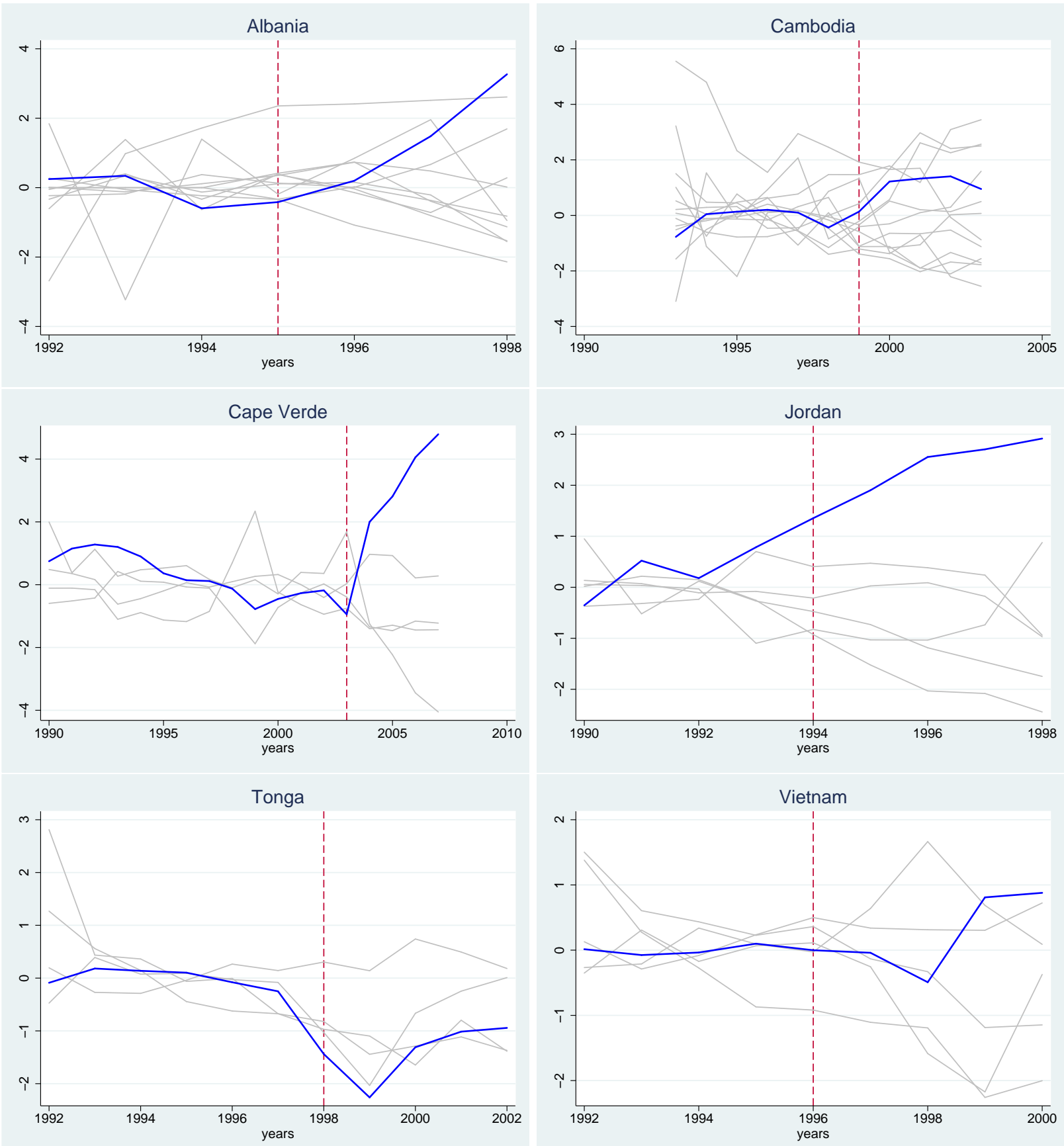

Notes: The figure depicts consumption taxes treatment effect for the respective country (bold line) and placebo treatment effects in the control countries. The vertical dashed line marks the date of WTO entry. 


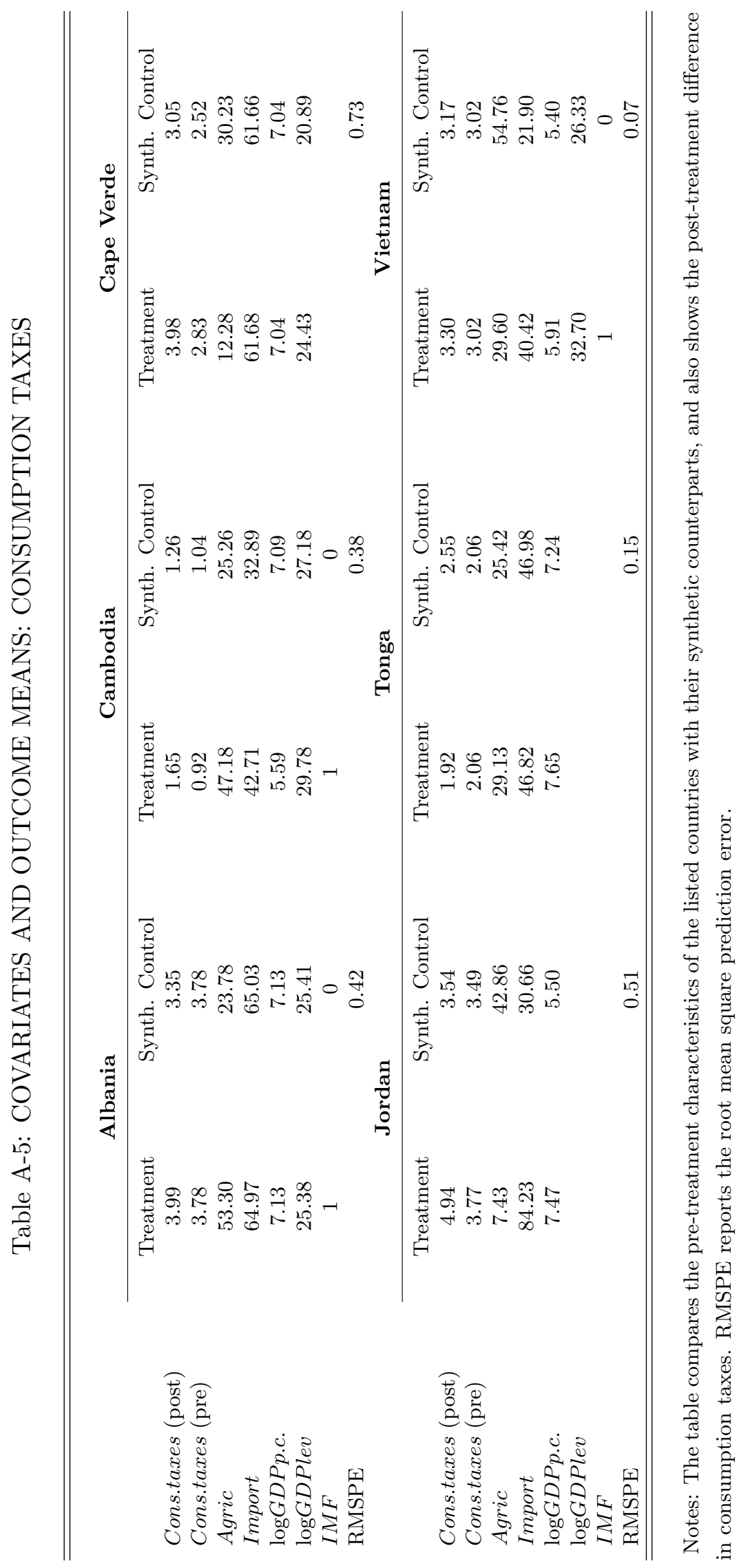




\section{References}

Abadie, A., Gardeazabal, J., 2003. The economic costs of conflict: a case study of the Basque country. American Economic Review 93 (1), 113-132.

Anderson, J. E., November 1996. Trade reform with a government budget constraint. NBER Working Paper 5827.

Angrist, J., Krueger, A.B., 2001. Instrumental variables and the search for identification: From supply and demand to natural experiments. Journal of Economic Perspectives 15(4), 69-85.

Autor, D. H., 2003. Outsourcing at will? The contribution of unjust dismissal doctrine to the growth of employment outsourcing. Journal of Labor Economics 21 (1), 1-42.

Baunsgaard, T., Keen, M., 2010. Tax revenue and (or?) trade liberalization. Journal of Public Economics 94, 563-577.

Baier, S. L., Bergstrand, J. H., 2007. "Do Free Trade Agreements Actually Increase Members International Trade?" Journal of International Economics 71, 72-95.

Bertrand, M., Duflo E., Mullainathan, S., 2004. How much should we trust differences-indifferences estimates. Quarterly Journal of Economics 119, 249-275.

Bhala, R., 2008. International Trade Law: Interdisciplinary Theory and Practice. Matthew Bender \& Company, Inc., Danvers.

Bird, R. M., Gendron, P., 2007. The VAT in Developing and Transitional Countries. Cambridge University Press, New York.

Bond, E. W., Ching, S., Lai, E. L.C., 2003. Game-theoretic analysis of China's WTO Accession. Pacific Economic Review 8, 117-125.

Clements, M. B. J., Inchauste, M. G., Thacker, M. N., Dorsey, M. T. W., Tareq, M. S., Baldacci, M. E., and Plant, M. M. W., 2002. Is the PRGF Living Up to Expectations? International Monetary Fund, Washington.

Davis, C. L., Wilf, M., 2011. Joining the Club: Accession to the GATT/WTO. Manuscript, September.

Emran, M. S., Stiglitz, J. E., 2003. Price-neutral Tax Reform with an Informal Economy. Manuscript, October. 
Emran, M. S., Stiglitz, J. E., 2005. On selective indirect tax reform in developing countries. Journal of Public Economics 89, 599-623.

Finger, J. M., Ingco, M.D., Reincke, U.,1996. The Uruguay Round: Statistics on Tariff Concessions Given and Received. The World Bank, Washington.

Greenway, D., Morgan, W., Wright, P., 2002. Trade liberalization and growth in developing countries. Journal of Development Economics 67, 229-244.

Hatzipanayotou, P., Michael S. M., Miller, S. M., 1994. Win-win indirect tax reform: a modest proposal. Economics Letters 44, 147-151.

Hawthorne, H., 2013. Least Developed Countries and the WTO. Special Treatment in Trade. Palgrave Macmillan, Hampshire.

Hoda, A., 2002. Tariff Negotiations and Renegotiations under the GATT and the WTO: Procedures and Practices. Cambridge University Press, Cambridge.

IFS and Mirrlees, J., (ed.) Tax by Design - The Mirrlees Review, Oxford 2011.

International Monetary Fund, 2005. Dealing with the revenue consequences of trade reform. International Monetary Fund, Washington.

Jones, K., 2009. The political economy of WTO accession: the unfinished business of universal membership. World Trade Review 8 (2), 279-314.

Keen, M., 2006. Is the VAT a money machine? National Tax Journal 59 (4), 905-928.

Keen, M., 2008. VAT, tariffs, and withholding: border taxes and informality in developing countries. Journal of Public Economics 92 (10), 1892-1906.

Keen, M., Ligthart, J.E., 2002. Coordinating tariff reduction and domestic tax reform. Journal of International Economics 56, 489-507.

Keen, M., Lockwood, B., 2010. The Value added tax: its causes and consequences. Journal of Development Economics 92, 138-151.

Khattry, B., Rao, J.M., 2002. Fiscal faux pas? An analysis of the revenue implications of trade liberalization. World Development 30 (8), 1431-1444.

Lechner, M., 2011. The estimation of causal effects by difference-in-difference methods. Foundations and Trends(R) in Econometrics 4 (3), 165-224. 
Linn, J. F., Wetzel, D. L., 1990. Public finance, trade and development. What have we learned, in: Tanzi, V. (Ed.), Fiscal Policies in Open Developing Economies. 9-28. International Monetary Fund, Washington, pp. 9-28

Malani, A., Reif, J., 2015. Interpreting pre-trends as anticipation: impact on estimated treatment effects from tort reform. Journal of Public Economics 124, 1-17.

Malhotra, K., 2003. Making Global Trade Work for People. Taylor \& Francis, New York.

Mitra, P., 1992. The coordinated reform of tariffs and indirect taxes. The World Bank Research Observer 7 (2), 195-218.

Pauwelyn, J., 2005. The transformation of world trade. Michigan Law Review 104 (1), 1-65.

Rose, A. K., 2004. Do WTO members have more liberal trade policy? Journal of International Economics 63, 209-235.

Rose, A. K., 2010. The effect of membership in the GATT/WTO on trade: where do we stand, in: Drabek, Z. (Ed.), Is the World Trade Organization Attractive Enough for Emerging Economies? Palgrave Macmillan, Hampshire, pp. 195-216.

Saner, R., Guilherme, R., 2007. The International Monetary Fund's influence on trade policies of low-income countries: a valid undertaking? Journal of World Trade 41 (5), 931-981.

Schenk, A., Oldman, O., 2007. Value Added Tax. A Comparative Approach. Cambridge University Press, New York.

Tait, A. A., 1986. Value Added Tax. International Practice and Problems. International Monetary Fund, Washington.

Tang, M., Wei, S., 2009. The value of making commitments externally: evidence from WTO accessions. Journal of International Economics 78, 216-229.

World Trade Organisation, 2009. A Handbook on Reading WTO Goods and Services Schedules. Cambridge University Press, New York. 